\title{
An acetyl-L-carnitine switch on mitochondrial dysfunction and rescue in the metabolomics study on aluminum oxide nanoparticles
}

Xiaobo Li ${ }^{1}$, Chengcheng Zhang ${ }^{1}$, Xin Zhang ${ }^{1}$, Shizhi Wang ${ }^{1}$, Qingtao Meng ${ }^{1}$, Shenshen Wu' ${ }^{1}$, Hongbao Yang ${ }^{2}$, Yankai $\mathrm{Xia}^{3+}$ and Rui Chen ${ }^{1,4^{*}+}$

\begin{abstract}
Background: Due to the wide application of engineered aluminum oxide nanoparticles and increased aluminum containing particulate matter suspending in air, exposure of human to nano-scale aluminum oxide nanoparticles $\left(\mathrm{Al}_{2} \mathrm{O}_{3} \mathrm{NPs}\right)$ is becoming inevitable.

Methods: In the present study, RNA microarray coupled with metabolomics analysis were used to uncover mechanisms underlying cellular responses to $\mathrm{Al}_{2} \mathrm{O}_{3} \mathrm{NPs}$ and imply the potential rescue.

Results: We found that $\mathrm{Al}_{2} \mathrm{O}_{3} \mathrm{NPs}$ significantly triggered down-regulation of mitochondria-related genes located in complex I, IV and V, which were involved in oxidative phosphorylation and neural degeneration pathways, in human bronchial epithelial (HBE) cells. Subsequent cell- and animal- based assays confirmed that $\mathrm{Al}_{2} \mathrm{O}_{3} \mathrm{NPs}_{\mathrm{s}}$ caused mitochondria-dependent apoptosis and oxidative stress either in vitro or in vivo, which were consistent with the trends of gene regulation. To rescue the $\mathrm{Al}_{2} \mathrm{O}_{3} \mathrm{NPs}$ induced mitochondria dysfunction, disruption of small molecular metabolites of HBE were profiled using metabolomics analysis, which facilitates identification of potential antagonizer or supplement against nanoparticle-involved damages. Supplementation of an antioxidant, acetyl-L-carnitine, completely or partially restored the $\mathrm{Al}_{2} \mathrm{O}_{3} \mathrm{NPS}$ modulated gene expression levels in mitochondrial complex I, IV and $\mathrm{V}$. It further reduced apoptosis and oxidative damages in both $\mathrm{Al}_{2} \mathrm{O}_{3} \mathrm{NPs}$ treated $\mathrm{HBE}$ cells and animal lung tissues.
\end{abstract}

Conclusion: Thus, our results demonstrate the potential mechanism of respiratory system damages induced by $\mathrm{Al}_{2} \mathrm{O}_{3} \mathrm{NPs}$. Meanwhile, based on the metabolomics profiling, application of acetyl-L-carnitine is suggested to ameliorate mitochondria dysfunction associated with $\mathrm{Al}_{2} \mathrm{O}_{3}$ NPs.

Keywords: Aluminum oxide nanoparticles, Mitochondria, Acetyl-L-carnitine, Nanotoxicology, Metabolomics

\section{Background}

Nano-scale aluminum oxide $\left(\mathrm{Al}_{2} \mathrm{O}_{3}\right)$ particles are widely used in insulator layers, powder coating, and fluorescent lamp material. Meanwhile, aluminum ( $\mathrm{Al})$ is a common metal component in ultrafine airborne particles $\left(\mathrm{PM}_{2.5}\right)$

\footnotetext{
*Correspondence: 101011816@seu.edu.cn

${ }^{\dagger}$ Equal contributors

${ }^{1}$ Key Laboratory of Environmental Medicine Engineering, Ministry of Education, School of Public Health, Southeast University, Dingjiaqiao 87, Nanjing 210009, China

${ }^{4}$ State Key Laboratory of Bioelectronics, Southeast University, Nanjing 210096, China

Full list of author information is available at the end of the article
}

in the ambient environment ${ }^{1,2}$ and is relatively stable in the form of aluminum oxide. These ultrafine aluminum particles have different physical, chemical, and biological characteristics, and are likely to be more toxic than the same conventional sized materials [1]. Thus, increased and inevitable occupational and environmental exposures to ultrafine $\mathrm{Al}_{2} \mathrm{O}_{3}$ particles are considered as a health risk, while, prevention or intervention measures have not been investigated. Generally, ultrafine particles can be inhaled more deeply than large particles, leaving sediment on the surface of the trachea, bronchus, and alveoli. Lung tissue is considered the primary target organ 
for inhaled ultrafine particles. Accordingly, aluminum oxide nanoparticles $\left(\mathrm{Al}_{2} \mathrm{O}_{3} \mathrm{NPs}\right)$ were employed as an ultrafine particle model to explore the impacts of aluminum ultrafine particles on the respiratory system.

Apoptosis is an endpoint to assess toxicity of metal oxide nanomaterial, providing a benchmark against which to evaluate the potential toxicity of engineered nanoparticles [2-4]. There are two major apoptotic pathways initiated by either mitochondria or cell surface receptors [5]. Mitochondria-mediated apoptosis is also called the 'intrinsic' pathway and occurs in response to a wide range of death stimuli, and is characterized by cascade reactions including mitochondrial outer membrane permeabilization (MOMP), release of cytochrome $c$ into the cytoplasm to activate caspase- 9 and subsequent caspase-3 $[5,6]$. The intrinsic pathway is involved in immune disorders [7], neurodegeneration [8] and cancer $[9,10]$. Studies investigating ambient particulate matter or nanoparticles suggest apoptosis or mitochondrial dysfunction are sufficient end-points to monitor toxicity [11-13], but conventional toxicity assays may not suffice to fully understand the cellular responses of ultrafine particle exposure. Thus, a more comprehensive approach to determining how cells respond to ultrafine particles is required.

"Omics" analysis, including transcriptomics, proteomics, and metabolomics, coupled with appropriate computational approaches to determine statistically significant gene, protein, metabolite or pathway regulation can be used as a tool to identify the potential hazards and mechanisms of nanoparticle toxicology [14-16]. These newly developed high-throughput approaches have been used to study the impact of nanomaterials, including metal and metal oxide nanoparticles [17-19]. In such studies, the "omics" technologies are used to predict interaction between nanoparticles and biological systems, facilitate assessment of systemic toxicity due to nanomaterials, reveal potential strategies for risk mitigation.

Metabolomics analysis is one of the most applied "omics" analysis that facilitates understanding of the modulation of small molecules following exposure. Acetyl-L-carnitine (ALCAR), an antioxidant dietary supplement, could be detected through GC/TOF/MS analysis and plays a vital role in oxidation of fatty acid metabolic pathways. It is a constituent of the inner mitochondrial membrane and has many fundamental functions, including acetyl CoA uptake [20], improving mitochondrial bioenergetics [21] and prevention of mitochondrial enzyme oxidation [22]. The acetyl group of ALCAR is used to produce the antioxidant glutathione (GSH), reducing oxidative stress, and protecting cells against lipid peroxidation [23, 24]. ALCAR also contributes to the bioenergetics processes, therefore, it plays a vital role in mitochondrial-related disorders $[25,26]$.
Here, we used human bronchial epithelia $(\mathrm{HBE})$ as a model system due to their importance in defense against inhaled pathogens and particulates [27]. We investigated changes in gene expression profiles and small molecular metabolites in $\mathrm{HBE}$ cells induced by $\mathrm{Al}_{2} \mathrm{O}_{3}$ NPs. Gene Ontology (GO) and the Kyoto Encyclopedia of Genes and Genomes (KEGG) were used to evaluate pathways. We showed that $\mathrm{Al}_{2} \mathrm{O}_{3}$ NPs are capable of triggering specific changes in $\mathrm{HBE}$ cell gene expression, specifically in mitochondria associated genes. We assessed mitochondriamediated apoptosis in the presence or absence of acetyl-Lcarnitine as a supplement to oppose mitochondrial dysfunction caused by $\mathrm{Al}_{2} \mathrm{O}_{3}$ NPs. The pathological alterations and ALCAR rescue were observed in mouse lung tissues treated with $\mathrm{Al}_{2} \mathrm{O}_{3}$ NPs. Our results suggests $\mathrm{Al}_{2} \mathrm{O}_{3}$ NPs cause toxicity and mitochondrial dysfunction that may be remedied by acetyl-L-carnitine treatment.

\section{Results}

\section{Overview of mRNA microarray profiles}

To determine how gene transcription was altered due to $\mathrm{Al}_{2} \mathrm{O}_{3}$ NP exposure, HBE cell mRNA profiling was evaluated by RNA microarray. As shown in Fig. 1a, $\mathrm{Al}_{2} \mathrm{O}_{3}$ nanoparticles exerted specific transcriptional effects leading to significantly increased expression of 54 genes and decreased expression of 304 genes, with a cutoff as 2 or more fold change and $P<0.05$. GO enrichment classifies transcriptional changes observed between control and treatment groups. Notably, the GO analysis revealed that genes encoding proteins necessary for mitochondrial function were differentially expressed. Significantly, of the genes differentially regulated, 23/ 154 genes involved in cell components (CC) (Fig. 1b); $11 / 85$ genes involved in molecular function (MF) (Fig. 1c), and 14/183 in biological process (Fig. 1d). These mitochondria involved enrichment were labeled with red color in Fig. 1. Therefore, a total of 27 mitochondrial related genes were identified, the fold change, $P$ value and functions of their encoded proteins are shown in Table 1.

Subsequently, these 27 genes were subjected to KEGG pathway enrichment analysis. These selected genes were annotated with the KEGG pathway database and hypergeometric tests were used to estimate the significance of enrichment. Among these pathways, mitochondrial function and neural system disease were significantly enriched (Fig. 2a). Figure 2b is schematic oxidative phosphorylation pathway by KEGG. Our microarray data suggested that $\mathrm{NADH}$ ubiquinone oxidoreductase-encoding genes (ND UFA2 and NDUFS4), NADH dehydrogenase-encoding genes located in mitochondrial complex 1 (NDUFC2, NDUFA1, and NDUFA4), NADH ubiquinol-cytochrome $c$ reductase gene UQCR11 (complex III), cytochrome $c$ oxidase genes (COX7B and COX17 (complex IV)), and the 
A

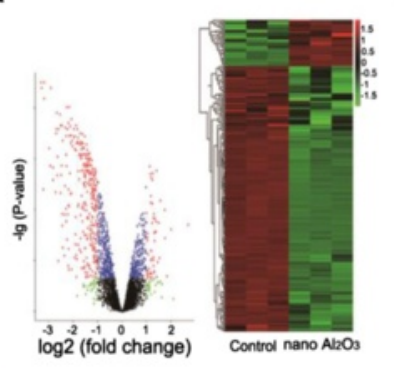

B

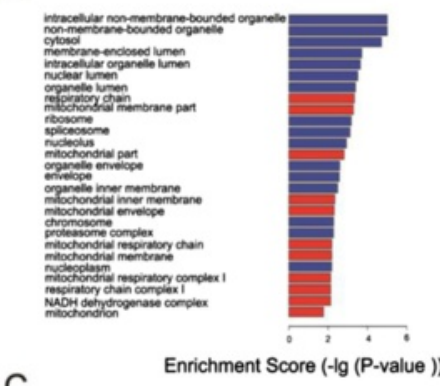

C

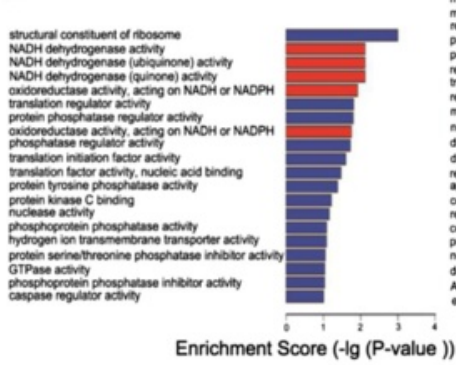

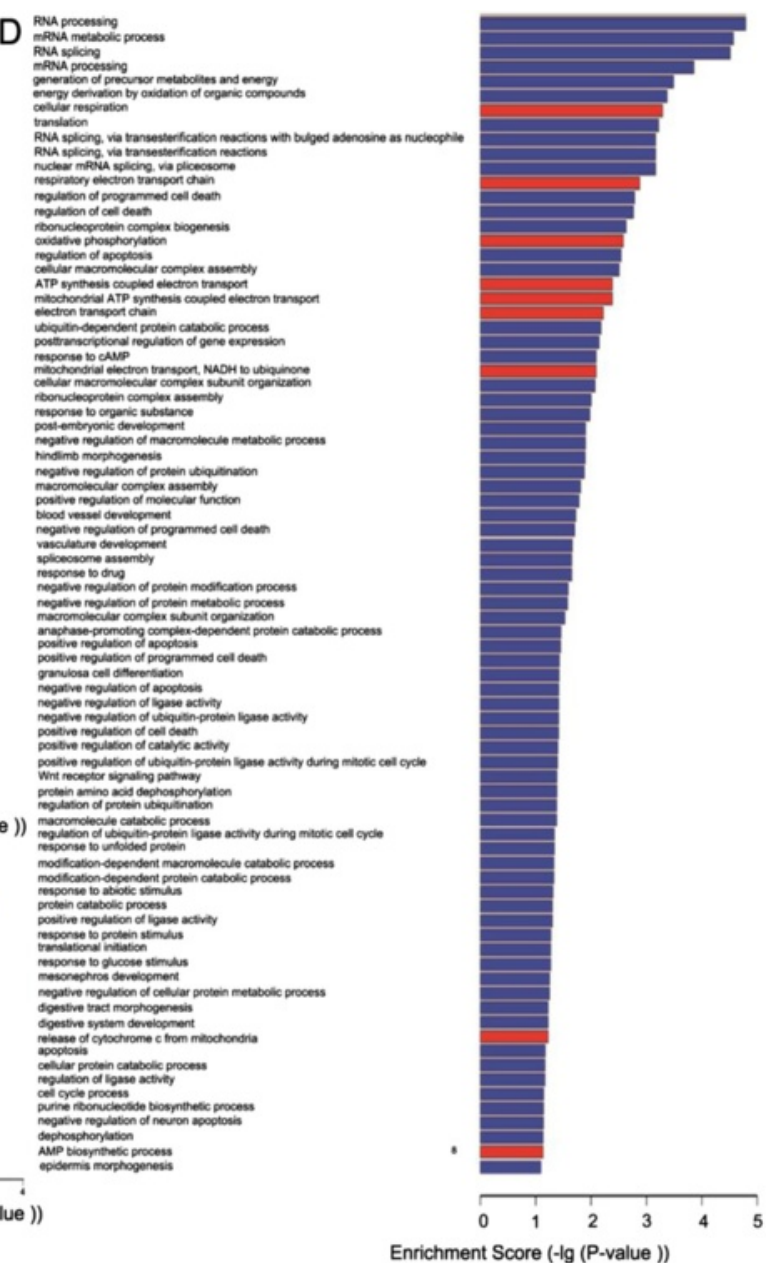

Enrichment Score (-Ig (P-value ))

Fig. 1 An overview of RNA microarray profiles. a Volcano diagram depicting the differentially expressed genes identified by a linear model of limma Software Package. Each red point corresponds to one differentially expressed gene. Heat map of samples based on the RNA microarray gene expression profiles. The down-regulation and up-regulation of genes were expressed by green color and red color correspondingly. b sub-ontology cellular component (CC) of gene ontology enrichment c) the sub-ontology molecular function (MF) shows mitochondria are the mostly involved enrichment categories. $\mathbf{d}$ sub-ontology of biological process (BP). The mitochondria-invovled GO enrichments were labeled with red

mitochondrial ATP synthase gene ATP5H (complex V, F0 unit) were among the most affected genes. The downregulated genes were noted with blue color and the upregulated gene was noted with red color in Fig. 2b.

\section{Levels of mRNA expression were confirmed by qRT-PCR}

To validate our RNA microarray data, we performed qRTPCR to validate 11 differentially expressed mitochondrial genes that involved in at least two enrichments in GO categories. In HBE cells and lung tissue obtained from mice treated with $\mathrm{Al}_{2} \mathrm{O}_{3}$ NPs, UQCR11 was upregulated and NDUFA4, NDUFA2, NDUFS4, COX7B, NDUFC2, ND UFA1, ATP5H, COX17, DLST, and CS were downregulated in a dose-dependent manner (Fig. 3a and b). With the exception of NDUFA4, which was down-regulated by qRT-PCR analysis, the trend in mRNA regulation of the other 10 genes was consistent between microarray and qRT-PCR (Fig. 3c).

\section{Apoptosis is induced in HBE cells and lung tissue following $\mathrm{Al}_{2} \mathrm{O}_{3} \mathrm{NPs}$ exposure}

Cytotoxicity of $\mathrm{Al}_{2} \mathrm{O}_{3}$ NPs was evaluated by CCK- 8 assay. $\mathrm{HBE}$ cells were exposed to $\mathrm{Al}_{2} \mathrm{O}_{3} \mathrm{NPs}$ at different doses $(12.5-1000 \mu \mathrm{g} / \mathrm{ml})$ every $24 \mathrm{~h}$ up to 7 days. $100 \mu \mathrm{g} / \mathrm{ml}$ or higher doses showed significant toxicity to HBE cells $24 \mathrm{~h}$ after treatment (Fig. 4a). To further verify that $\mathrm{Al}_{2} \mathrm{O}_{3}$ NP exposure caused apoptosis, cells was assessed by flow cytometric analysis of annexin V-FITC and PI double staining. After $12 \mathrm{~h}$ treatment, significant enhancement of apoptosis $(2.24 \pm 0.17 \%)$ was observed only in $500 \mu \mathrm{g} / \mathrm{mL} \mathrm{Al}_{2} \mathrm{O}_{3}$ NPs $\mathrm{HBE}$ cells (Additional file 1: Figure S1A). Further, apoptosis occurred $8.98 \pm 0.39 \%$ and $16.77 \pm 0.57 \%$ in HBE cells treated with 100 or 
Table 1 Modulated genes involved in mitochondrial functions

\begin{tabular}{|c|c|c|c|}
\hline $\begin{array}{l}\text { Gene } \\
\text { symbol }\end{array}$ & Main functions & $\begin{array}{l}\text { Adjusted } \\
P \text { value }\end{array}$ & $\begin{array}{l}\text { Fold } \\
\text { change }\end{array}$ \\
\hline NDUFA4 & $\begin{array}{l}\text { NADH dehydrogenase [ubiquinone] } \\
1 \text { alpha subcomplex subunit } 4\end{array}$ & $6.73 \mathrm{E}-06$ & 2.365756 \\
\hline NDUFA2 & $\begin{array}{l}\text { NADH dehydrogenase [ubiquinone] } \\
1 \text { alpha subcomplex subunit } 2 \\
\text { isoform } 1\end{array}$ & $3.02 \mathrm{E}-06$ & 0.374527 \\
\hline NDUFS4 & $\begin{array}{l}\text { NADH dehydrogenase [ubiquinone] } \\
\text { iron-sulfur protein 4, mitochondrial } \\
\text { precursor }\end{array}$ & 4.13E-06 & 0.396259 \\
\hline UQCR11 & $\begin{array}{l}\text { ubiquinol-cytochrome c reductase, } \\
\text { complex III subunit XI [Source:HGNC } \\
\text { Symbol;Acc:30862] }\end{array}$ & 4.01E-06 & 2.23789 \\
\hline COX7B & $\begin{array}{l}\text { cytochrome c oxidase subunit 7B, } \\
\text { mitochondrial precursor }\end{array}$ & $2.16 \mathrm{E}-07$ & 0.284784 \\
\hline NDUFC2 & $\begin{array}{l}\mathrm{NADH} \text { dehydrogenase [ubiquinone] } \\
1 \text { subunit } \mathrm{C} 2 \text { isoform } 1\end{array}$ & 4.23E-07 & 0.262135 \\
\hline NDUFA1 & $\begin{array}{l}\text { NADH dehydrogenase [ubiquinone] } \\
1 \text { alpha subcomplex subunit } 1\end{array}$ & $3.91 \mathrm{E}-08$ & 0.217706 \\
\hline ATP5H & $\begin{array}{l}\text { ATP synthase subunit } d \text {, mitochondrial isoform } \\
\text { b }\end{array}$ & $3.12 \mathrm{E}-06$ & 0.400955 \\
\hline TXNDC17 & $\begin{array}{l}\text { thioredoxin domain-containing } \\
\text { protein } 17\end{array}$ & $9.85 \mathrm{E}-03$ & 2.426058 \\
\hline ATP5S & $\begin{array}{l}\text { ATP synthase subunit s, mitochondrial isoform } \\
\text { b precursor }\end{array}$ & $6.20 \mathrm{E}-03$ & 0.273283 \\
\hline ATP6V0B & $\begin{array}{l}\text { V-type proton ATPase } 21 \mathrm{kDa} \\
\text { proteolipid subunit isoform } 2\end{array}$ & $1.34 \mathrm{E}-03$ & 0.450262 \\
\hline CS & $\begin{array}{l}\text { citrate synthase, mitochondrial } \\
\text { precursor }\end{array}$ & 7.27E-05 & 0.464647 \\
\hline DLST & $\begin{array}{l}\text { dihydrolipoyllysine-residue } \\
\text { succinyltransferase component of } \\
\text { 2-oxoglutarate dehydrogenase complex, } \\
\text { mitochondrial isoform } 1 \text { precursor }\end{array}$ & 4.25E-04 & 0.486408 \\
\hline JUN & transcription factor AP-1 & 8.43E-04 & 0.447503 \\
\hline NDUFB11 & $\begin{array}{l}\text { NADH dehydrogenase [ubiquinone] } \\
1 \text { beta subcomplex subunit } 11, \\
\text { mitochondrial isoform } 1\end{array}$ & $2.57 \mathrm{E}-02$ & 2.051124 \\
\hline SOD2 & $\begin{array}{l}\text { superoxide dismutase }[\mathrm{Mn}] \\
\text { mitochondrial isoform A precursor }\end{array}$ & 6.44E-06 & 0.476653 \\
\hline TP73 & tumor protein p73 isoform d & $2.15 \mathrm{E}-02$ & 0.403954 \\
\hline ATPIF1 & $\begin{array}{l}\text { ATPase inhibitor, mitochondrial } \\
\text { isoform } 1 \text { precursor }\end{array}$ & $8.80 \mathrm{E}-04$ & 2.074952 \\
\hline $\operatorname{cox} 17$ & $\begin{array}{l}\text { cytochrome c oxidase copper } \\
\text { chaperone }\end{array}$ & $6.79 \mathrm{E}-08$ & 0.255958 \\
\hline MRPL11 & $\begin{array}{l}395 \text { ribosomal protein } \mathrm{L} 11 \text {, } \\
\text { mitochondrial isoform a }\end{array}$ & 4.50E-06 & 0.159154 \\
\hline PMPCB & $\begin{array}{l}\text { mitochondrial-processing peptidase } \\
\text { subunit beta precursor }\end{array}$ & 4.50E-06 & 0.352621 \\
\hline CYP11A1 & $\begin{array}{l}\text { cholesterol side-chain cleavage } \\
\text { enzyme, mitochondrial isoform a } \\
\text { precursor }\end{array}$ & 4.45E-05 & 2.955856 \\
\hline MRPL52 & mitochondrial ribosomal protein $L 52$ & $2.41 \mathrm{E}-05$ & 0.452092 \\
\hline $\mathrm{HAAO}$ & 3-hydroxyanthranilate 3,4-dioxygenase & $1.34 \mathrm{E}-03$ & 0.376486 \\
\hline TOMM20 & $\begin{array}{l}\text { mitochondrial import receptor subunit } \\
\text { TOM20 homolog }\end{array}$ & $6.86 \mathrm{E}-07$ & 0.321764 \\
\hline MRPL39 & $\begin{array}{l}39 S \text { ribosomal protein } L 39 \text {, } \\
\text { mitochondrial isoform b }\end{array}$ & $1.16 \mathrm{E}-06$ & 0.38445 \\
\hline HSPE1 & $\begin{array}{l}10 \mathrm{kDa} \text { heat shock protein, } \\
\text { mitochondrial }\end{array}$ & $2.73 \mathrm{E}-08$ & 0.239258 \\
\hline
\end{tabular}

$500 \mu \mathrm{g} / \mathrm{mL} \mathrm{Al}_{2} \mathrm{O}_{3}$ NPs for $24 \mathrm{~h}$, respectively, but significant increase of cellular necrosis was not observed at either treatment concentrations (Fig. 4b). To determine pathways induced by $\mathrm{Al}_{2} \mathrm{O}_{3} \mathrm{NP}$ exposure, caspase-3, 8, and -9 activities were evaluated. Increased activities of caspase-3 and -9 were shown in $\mathrm{Al}_{2} \mathrm{O}_{3}$ NPs treated groups, suggesting $\mathrm{HBE}$ cell apoptosis is initiated by the intrinsic pathway (Fig. 4c). Similar results were obtained from lung tissues harvested from mice treated with $\mathrm{Al}_{2} \mathrm{O}_{3}$ NPs (Fig. 4c).

H\&E and TUNEL staining was performed to detect pathology and programmed cell death in situ. Inflammation and red blood cell located in pulmonary mesenchyme were observed in both low and high dose exposed mice lung tissue. The typical pathological alterations were showed in Fig. 5. Figure 5a showed a normal structure of lung tissue. As shown in Fig. 5b, pneumorrhagia characterized by interstitial red blood cells distribution was seen in lung tissue obtained from mice treated with low dose $\mathrm{Al}_{2} \mathrm{O}_{3}$ NPs. Massive lymphocytes infiltration, especially the subpleural area, were observed in high dose $\mathrm{Al}_{2} \mathrm{O}_{3}$ NPs treated mice lung tissue (Fig. 5c). The pathological lesions scores were showed in Fig. 5g. Compared with control group, the pathological lesion score increased significantly in both nanoparticle treated lung tissues $(P<0.05)$, However, high dose exposure did not enhance the pathological lesions in lung tissue significantly when compared with low $\mathrm{Al}_{2} \mathrm{O}_{3}$ NPs treatment. For both treatment groups, pathological scores suggested mild to moderate alveolitis in lung tissues of mice, further, following ALCAR rescue, the alveolitis were attenuated to mild degree. ALCAR ameliorated the damages against $\mathrm{Al}_{2} \mathrm{O}_{3}$ NPs significantly $(P<0.05)$, compared with corresponding $\mathrm{Al}_{2} \mathrm{O}_{3} \mathrm{NPs}$ treated groups.

TUNEL-positive cells were not observed in the bronchial epithelia in untreated mice lung (Fig. 5d). Treatment with $10 \mathrm{mg} / \mathrm{m}^{3} \mathrm{Al}_{2} \mathrm{O}_{3}$ NPs resulted in degeneration of lung cells and the massive bronchial epithelial cells had significant apoptosis (Fig. 5e) Ameliorated apoptosis was observed in bronchial epithelia of mice exposed to high dose $\mathrm{Al}_{2} \mathrm{O}_{3}$ NPs following ALCAR rescue (Fig. 5f). The proportion of TUNEL-positive bronchial epithelia were showed in Fig. 5h. For both low and high dose $\mathrm{Al}_{2} \mathrm{O}_{3}$ NPs treatment, ALCAR could partially rescue apoptosis of bronchial epithelia to control level.

\section{Dysfunction of mitochondria induced by $\mathrm{Al}_{2} \mathrm{O}_{3} \mathrm{NPs}$}

The mitochondria-mediated apoptosis pathway is characterized by destruction of mitochondrial membrane potential and subsequent release of cytochrome $c$ into the cytoplasm [6], accompanied by decreased ATP synthesis. The fluorescent probe JC-1 staining showed red fluorescence in normal cells, indicating intact mitochondrial membrane potential, while cells treated with 100 and $500 \mu \mathrm{g} / \mathrm{ml} \mathrm{Al}_{2} \mathrm{O}_{3}$ NPs were stained green after 12 or 


\section{A}

hsa00190:Oxidative phosphorylation

hsa05016:Huntington's disease

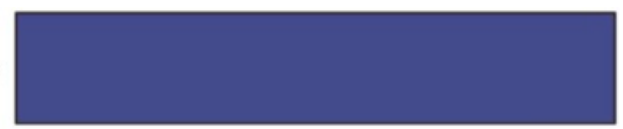

hsa05012:Parkinson's disease

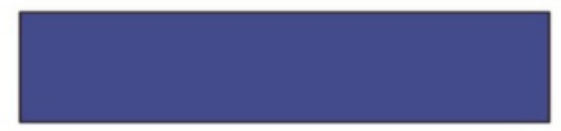

hsa05010:Alzheimer's disease

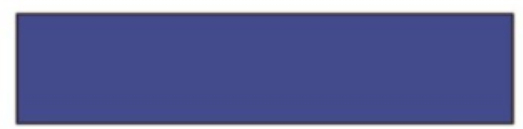

hsa00020: Citrate cycle (TCA cycle)
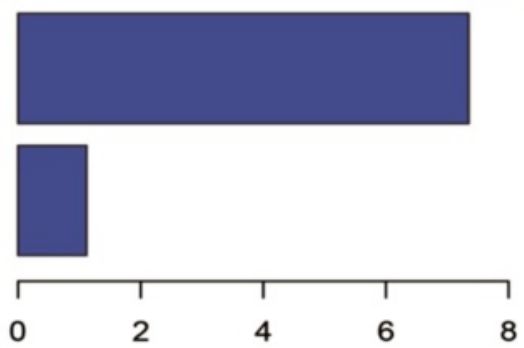

Enrichment Score(-log10Pvalue)

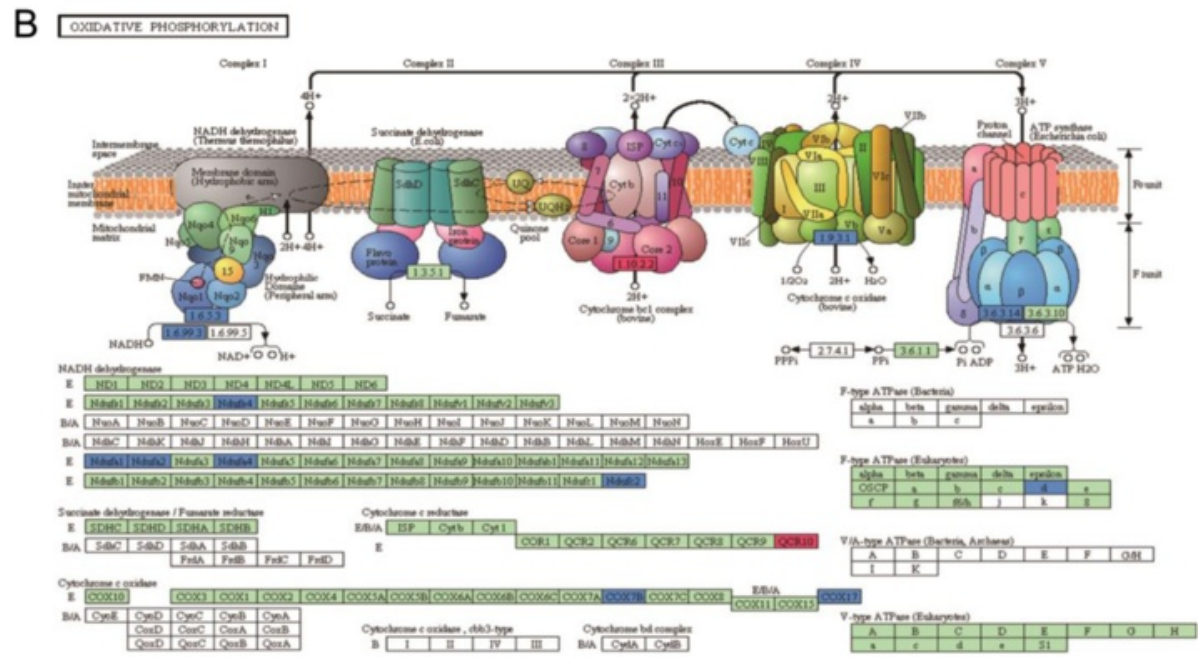

Fig. 2 KEGG pathway enrichment analysis of mitochondria related genes. a A total of 27 mitochondria related genes were analyzed through DAVID functional annotation cluster tool. These genes mainly are involved in five KEGG pathways. Oxidative phosphorylation is the most significant enrichment. b A schematic figure of the oxidative phosphorylation pathway by KEGG. mRNA microarray assay predicted up-regulated genes are stainded red, and down-regulated genes are stained blue in this schematic figure

$24 \mathrm{~h}$ treatment, indicating clear damage to the mitochondrial membrane potential as shown in Additional file 1: Figure S1B and Fig. 6a. Additionally, cytoplasmic cytochrome $c$ significantly increased in cells treated with $\mathrm{Al}_{2} \mathrm{O}_{3}$ NPs (Fig. 6b), however, this was lower than the positive control (CCCP).

ATP levels were detected by luminometer after $24 \mathrm{~h}$ exposure. In both HBE cells and lung tissues from mice treated with $\mathrm{Al}_{2} \mathrm{O}_{3}$ NP, ATP decreased compared to the control (Fig. 6b). Collectively, our results suggest $\mathrm{Al}_{2} \mathrm{O}_{3}$ NPs exposure is cytotoxic.
$\mathrm{Al}_{2} \mathrm{O}_{3} \mathrm{NPs}$ induce oxidative stress in both $\mathrm{HBE}$ cells and mice lung tissues

To assess the importance of oxidative stress in $\mathrm{Al}_{2} \mathrm{O}_{3}$ NP cytotoxicity, ROS, $\mathrm{H}_{2} \mathrm{O}_{2}, \mathrm{O}_{2}^{-}$and MDA levels were evaluated in HBE cells 12 or $24 \mathrm{~h}$ after treatment. Correspondingly, ROS and MDA levels were evaluated in mice lung tissues. ROS generation is a main cause of mitochondria-dependent apoptosis. We used DCFH-DA as a reporter of ROS generation, and as shown in Fig. 7a, level of ROS increased in cells treated with $\mathrm{Al}_{2} \mathrm{O}_{3} \mathrm{NPs}$ for $24 \mathrm{~h}$, indicated by higher intensity of fluorescence. 
Li et al. Particle and Fibre Toxicology (2016) 13:4

Page 6 of 19
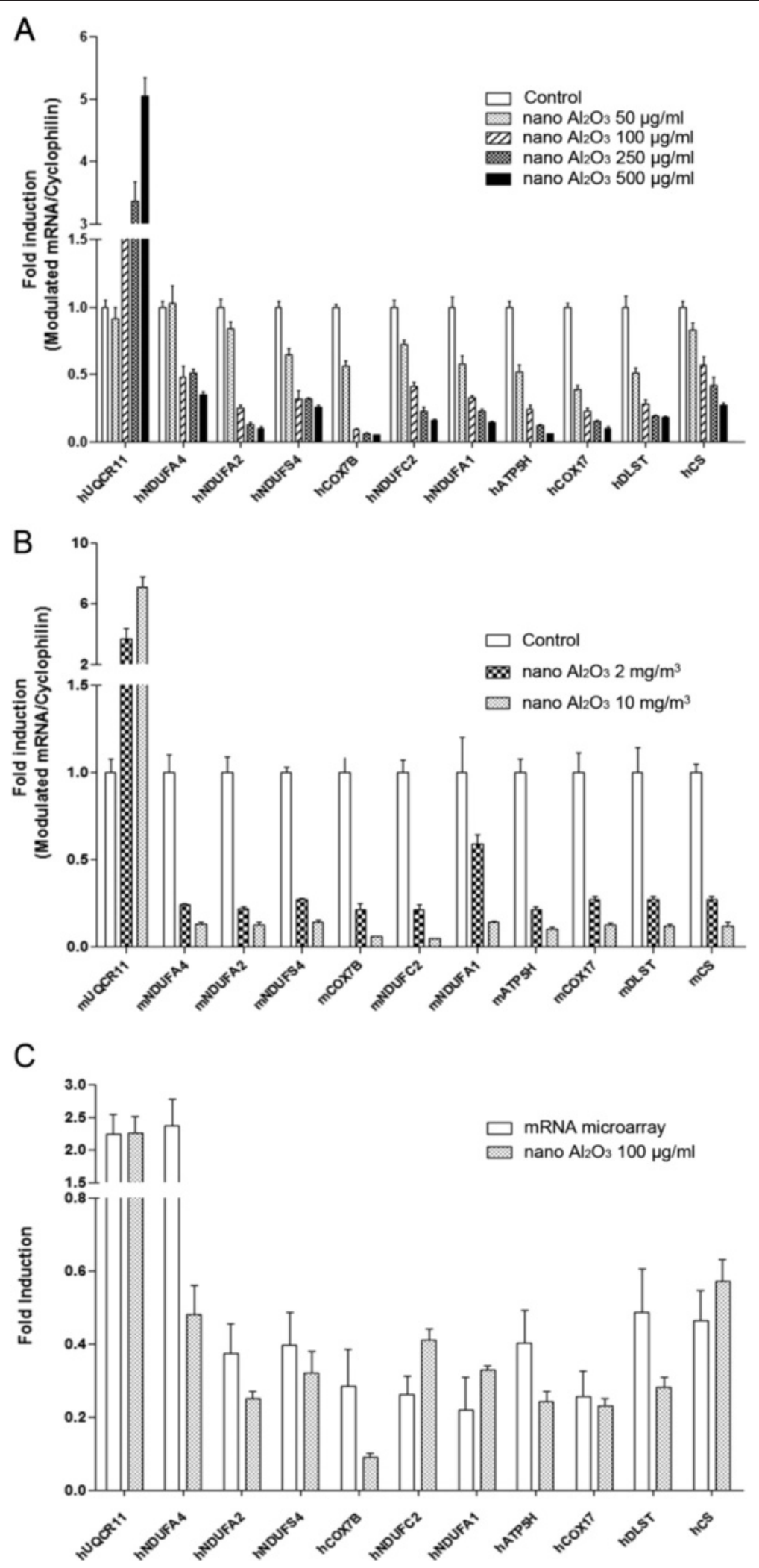

Fig. 3 (See legend on next page.) 
(See figure on previous page.)

Fig. 3 qRT-PCR validation of the expression levels of modulated mitochondria-related mRNA. a Mitochondria-related gene expression level in HBE cells treated with $50,100,250$ or $500 \mu \mathrm{g} / \mathrm{ml} \mathrm{Al}_{2} \mathrm{O}_{3} \mathrm{NPs}$. Gene expression is regulated in a dose-dependent manner $\mathbf{b}$ : Gene expression level of lung tissues in mice exposed to $\mathrm{Al}_{2} \mathrm{O}_{3}$ NPs through inhalation. Gene expression is regulated in a dose-dependent manner. c Except NDUFA4, fold change of modulated genes in cells treated with $100 \mu \mathrm{g} / \mathrm{ml} \mathrm{Al}_{2} \mathrm{O}_{3} \mathrm{NPs}$ are consistent with array data

As shown in Additional file 1: Figure S1C and Fig. 7b, $\mathrm{Al}_{2} \mathrm{O}_{3} \mathrm{NP}$ treatment significantly increased $\mathrm{ROS}$ and $\mathrm{O}_{2}^{-}$ levels, but not $\mathrm{H}_{2} \mathrm{O}_{2}$ levels, in HBE cells. Comparable results were observed in lungs obtained from mice treated with $\mathrm{Al}_{2} \mathrm{O}_{3}$ NPs. Similarly, MDA, the end product of lipid peroxidation, also increased as shown in Fig. $7 \mathrm{~b}$ and Additional file 1: Figure S1C. For all of these oxidative stress-involved assays, the positive control (CCCP) demonstrated stronger stimulus to $\mathrm{HBE}$ cells than $\mathrm{Al}_{2} \mathrm{O}_{3} \mathrm{NPs}$.

\section{Metabolic analysis showed up- and down- regulated metabolites of HBE cells}

According to PCA analysis, significant differences were observed between control $\mathrm{HBE}$ cells and $\mathrm{HBE}$ cells treated with either $100 \mu \mathrm{g} / \mathrm{ml}$ or $500 \mu \mathrm{g} / \mathrm{ml} \mathrm{Al}_{2} \mathrm{O}_{3} \mathrm{NPs}$ (Additional file 1: Figure S2). We used MetaboAnalyst to identify key metabolism alterations between untreated and treated HBE cells. After Bonferroni correction ( $p$ cut-off $<0.00001$ ), we found 9 down-regulated and 11 up-regulated small molecules in treated samples in a dose-dependent manner (Table 2). Among differentially regulated metabolites, acetyl-L-carnitine (ALCAR) $(p=$ $\left.3.64 \mathrm{E}^{-09}\right)$, 4-Methoxyphenylacetic acid $\left(p=7.61 \mathrm{E}^{-07}\right)$ and thymine $\left(p=2.99 \mathrm{E}^{-07}\right)$ were the lowest in $P$ value. Because ALCAR is important for mitochondrial function, it could be a candidate supplement to rescue the adverse effects of $\mathrm{Al}_{2} \mathrm{O}_{3} \mathrm{NPs}$ on HBE cells.

\section{Protective effects of ALCAR to HBE cells against $\mathrm{Al}_{2} \mathrm{O}_{3}$ NPs induced mitochondria dysfunction and oxidative stress}

To test whether ALCAR could reduce cell toxicity due to $\mathrm{Al}_{2} \mathrm{O}_{3} \mathrm{NPs}$, toxicity was evaluated in cells treated with 0.1 or $0.3 \mathrm{mg} / \mathrm{ml} \mathrm{ALCAR}$ at treatment with $500 \mu \mathrm{g} / \mathrm{ml}$ $\mathrm{Al}_{2} \mathrm{O}_{3}$ NPs. As shown in Fig. 8a, $0.3 \mathrm{mg} / \mathrm{ml}$ ALCAR treatment significantly reduced the cell viability loss in both 100 and $500 \mu \mathrm{g} / \mathrm{ml} \mathrm{Al}_{2} \mathrm{O}_{3} \mathrm{NP}$ treated cells, and was used as a therapeutic dose for the remaining experiments. Compared to untreated cells and lungs, cotreatment with ALCAR attenuated caspase-3 and -9 activities as shown in Fig. 8b. Caspase-8 activity was not affected by ALCAR treatment (Fig. 8b). To confirm ALCAR treatment reduced apoptosis, treated cells were evaluated by annexin-V and PI staining. Similarly, $0.3 \mathrm{mg} / \mathrm{ml}$ ALCAR treatment reduced annexin-V staining significantly (Fig. 8c). ALCAR treatment also reduced production of intracellular ROS, $\mathrm{O}_{2}^{-}$and MDA in $\mathrm{HBE}$ cells and lungs harvested from mice treated with
$\mathrm{Al}_{2} \mathrm{O}_{3}$ NPs as shown in Fig. 9a and b. ALCAR could only partially rescue HBE cells against CCCP induced oxidative stress (Fig. 9a). ALCAR also demonstrated protective effects to mice bronchia epithelia from apoptosis (Fig. 5f).

Gene expression levels in HBE cells and mouse lung tissues after ALCAR treatment were evaluated by qRTPCR. Altered expression of genes located in mitochondria complex IV and V, COX7B, COX17 and ATP5H, was comparable to control cells following ALCAR treatment. Expression of genes in complex I, including NDUFA1, NDUFA2, NDUFA4, NDUFC2 and NDUFS4 were partially normalized following ALCAR treatment. UQCR11, DLST, and CS expression was unresponsive to ALCAR treatment (Fig. 10).

\section{Discussion}

Using high-throughput mRNA sequencing and computational approaches, we showed that $\mathrm{Al}_{2} \mathrm{O}_{3}$ NPs cause changes in gene expression in HBE cells. Among the differentially expressed genes, mitochondrial genes were among the most significantly affected category. Further, cell and animal based functional assays confirmed that $\mathrm{Al}_{2} \mathrm{O}_{3}$ NPs caused mitochondrial dysfunction and oxidative stress in HBE cells and mouse lung tissue. Metabolomics analysis showed downregulation of ALCAR in $\mathrm{HBE}$ lysate in a dose-dependent manner following $\mathrm{Al}_{2} \mathrm{O}_{3}$ NP treatments. Co-treatment of cells with ALCAR and $\mathrm{Al}_{2} \mathrm{O}_{3}$ NPs prevented mitochondrial dysfunction both in vivo and in vitro.

Inhalation is one of the major exposure routes for nano-scale materials, including engineered nanoparticles and ambient particulate matter (PM), which have effects on the respiratory system [28]. Various nanoparticles are reported to produce pulmonary lesions. For example, respiratory administration of single-walled carbon nanotubes (SWCNTs) increased collagen and alveolar wall thickness [29]. Well dispersed nickel-oxide nanoparticles increase inflammation and cytotoxicity in C57BL/6 J mice lung tissues [30]. Transcriptomic and proteomic approaches implicate that inflammation and oxidative stress are involved in pulmonary toxicity caused by silica nanoparticles [31]. Chronic exposure to ambient PM can cause lung remodeling, with particle deposition on terminal bronchioles and first-generation respiratory bronchioles [32]. Though aluminum is considered as a neural toxin, lung tissue could be the primary organ affected by inhaled nano-scale $\mathrm{Al}_{2} \mathrm{O}_{3}$ particles from either 

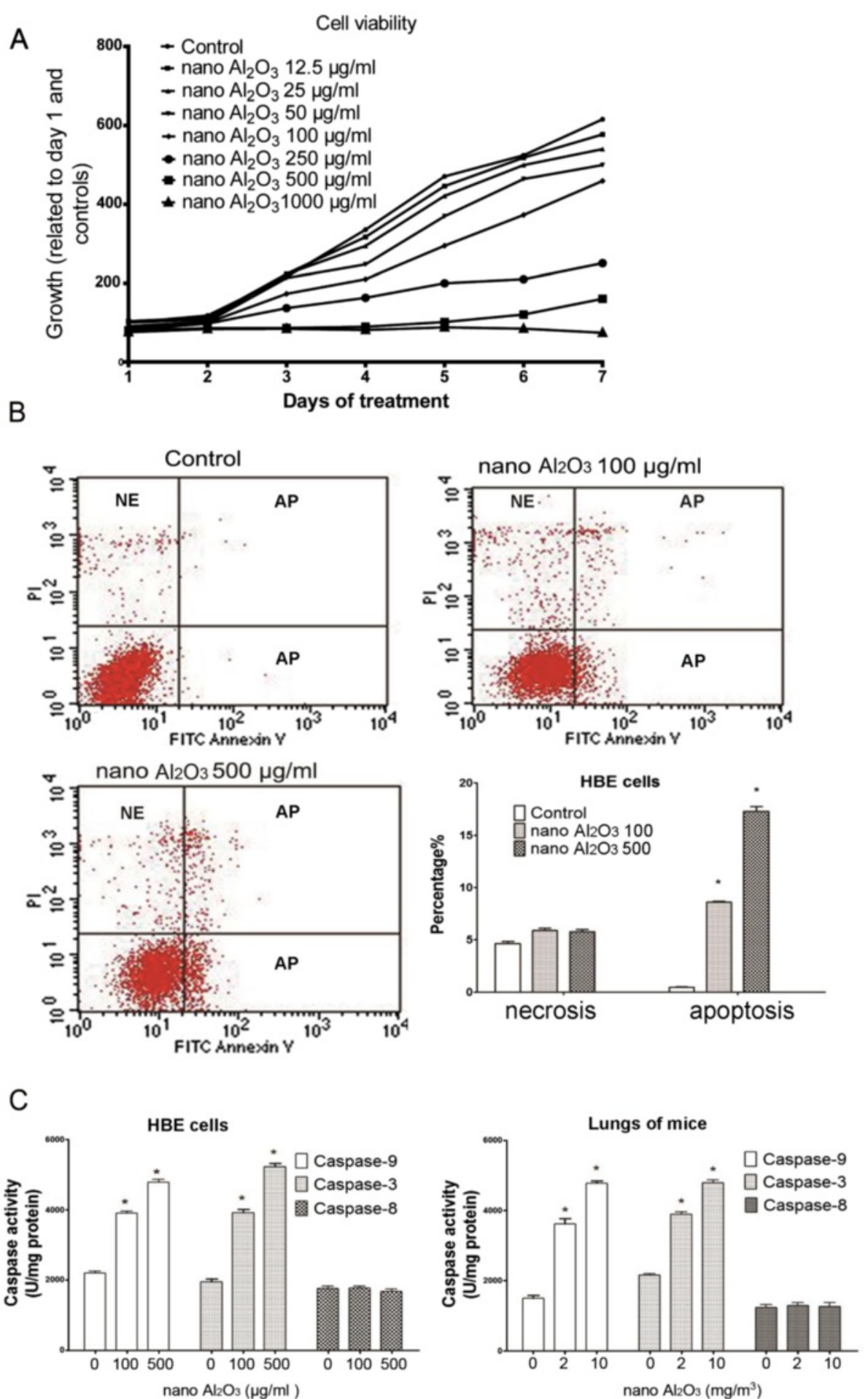

Fig. 4 Cell viability and apoptosis of HBE cells after exposure to $\mathrm{Al}_{2} \mathrm{O}_{3} \mathrm{NPS}$. a Cell viability of HBE cells were analyzed through CCK-8 assays after exposure to $\mathrm{Al}_{2} \mathrm{O}_{3} \mathrm{NPs}$. $\mathbf{b}$ Apoptosis induction was significantly enhanced by $\mathrm{Al}_{2} \mathrm{O}_{3} \mathrm{NP}$ exposure, and the proportion of necrosis was not significantly modulated c) Assessments of caspase-3, -8 , and -9 activities in $\mathrm{HBE}$ cells and lung tissues harvested from mice treated with $\mathrm{Al}_{2} \mathrm{O}_{3} \mathrm{NPs}$. The increase of caspase- -9 and -3 suggested that $\mathrm{Al}_{2} \mathrm{O}_{3}$ NPs induced apoptosis in $\mathrm{HBE}$ are mitochondria involved. ${ }^{*} P<0.05$, compared with untreated control 

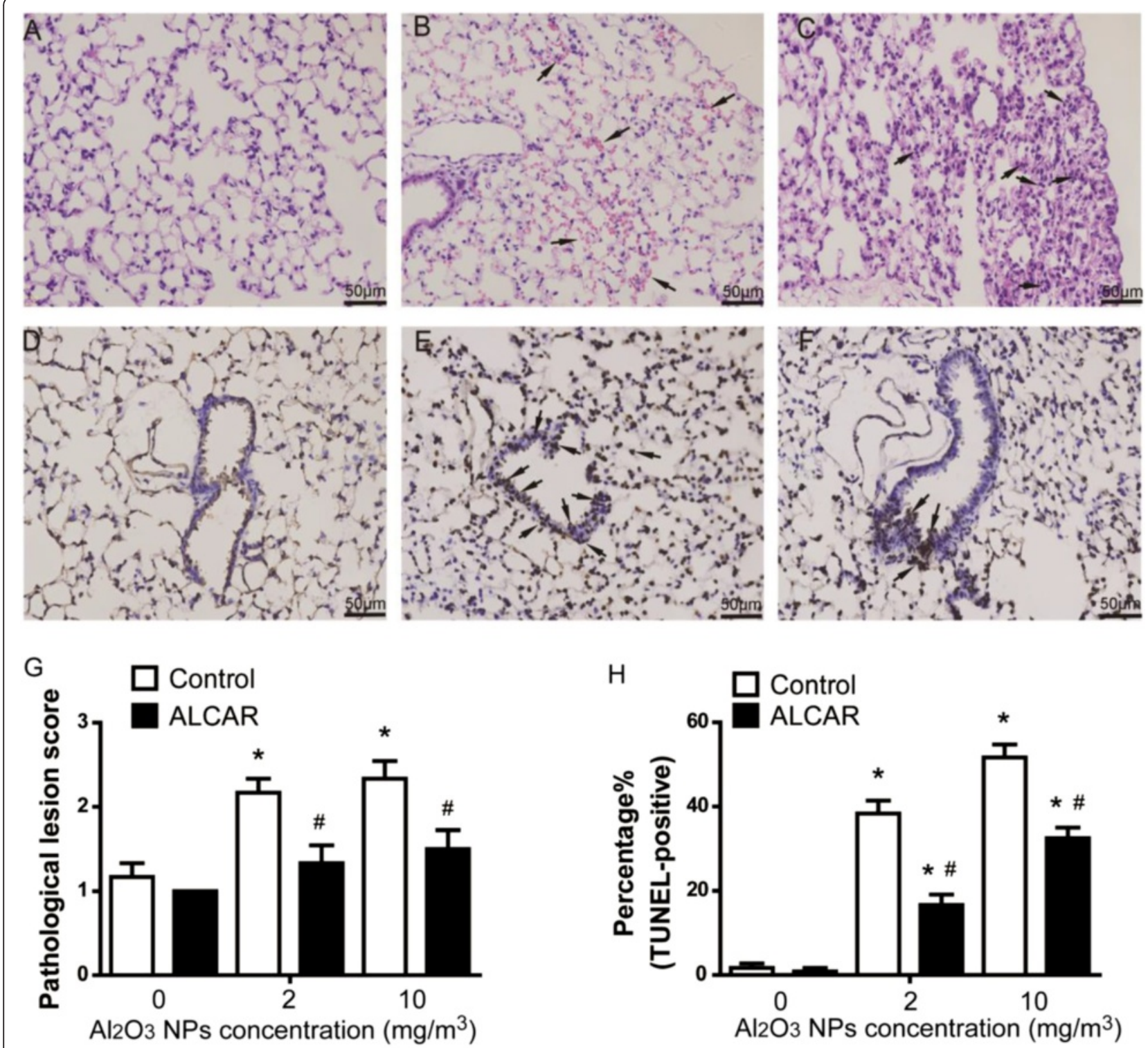

Fig. $5 \mathrm{HE}$ and TUNEL staining of lung tissues harvested from mice exposed to $\mathrm{Al}_{2} \mathrm{O}_{3} \mathrm{NPs}$. a HE staining of control mice lung tissue b) arrows showed pneumorrhagia in lung tissue from $2 \mathrm{mg} / \mathrm{m}^{3} \mathrm{Al}_{2} \mathrm{O}_{3} \mathrm{NP}$ exposure c) arrows demonstrated lymphocytes infiltration of lung tissue due to exposure to $10 \mathrm{mg} / \mathrm{m}^{3} \mathrm{Al}_{2} \mathrm{O}_{3} \mathrm{NPs} \mathbf{d}$ ) few apoptosis cells were observed in control mice lung tissue by TUNEL staining e) massive apoptosis in bronchial epithelia were induced by $10 \mathrm{mg} / \mathrm{m}^{3} \mathrm{Al}_{2} \mathrm{O}_{3} \mathrm{NP}$ exposure as shown by arrows $\mathbf{f}$ ) ALCAR supplement reduced apoptosis of bronchial epithelia in $10 \mathrm{mg} / \mathrm{m}^{3} \mathrm{Al}_{2} \mathrm{O}_{3} \mathrm{NP}$ exposed mice lung tissue. The arrows show apoptotic epithelial cells. $\mathbf{g}$ The pathological lesion score of mice lung tissues $\mathbf{h}$ ) Proportion of TUNEL-positive bronchial epithelia within each group. ${ }^{*} P<0.05$, compared with untreated control. ${ }^{\#} P<0.05$, compared with corresponding control

engineered or ambient sources. According to the Chinese Health standard for dusts of aluminum, aluminum oxide, and aluminum alloys in the air of workplace (GB1172689), the maximum allowable concentration for $\mathrm{Al}_{2} \mathrm{O}_{3}$ powder in air is $6 \mathrm{mg} / \mathrm{m}^{3}$. Among these suspended particles, the health effects of nano-scaled $\mathrm{Al}_{2} \mathrm{O}_{3}$ particles should be intensively considered due to its longer suspension and lower deposition in respiratory system than other large particles. In the present study, the exposure doses of
$\mathrm{Al}_{2} \mathrm{O}_{3}$ NPs to mice were set to 2 or $10 \mathrm{mg} / \mathrm{m}^{3}$ to evaluate the potential pulmonary damages.

Mitochondrial function was used as an indicator to evaluate the biological effects of various nanomaterials [33]. Copper oxide nanoparticles induce apoptosis in human hepato-carcinoma (HEPG2) cells through the intrinsic apoptosis pathway, which is accompanied by increased reactive oxygen species generation and oxidative stress and the collapse of mitochondria membrane 


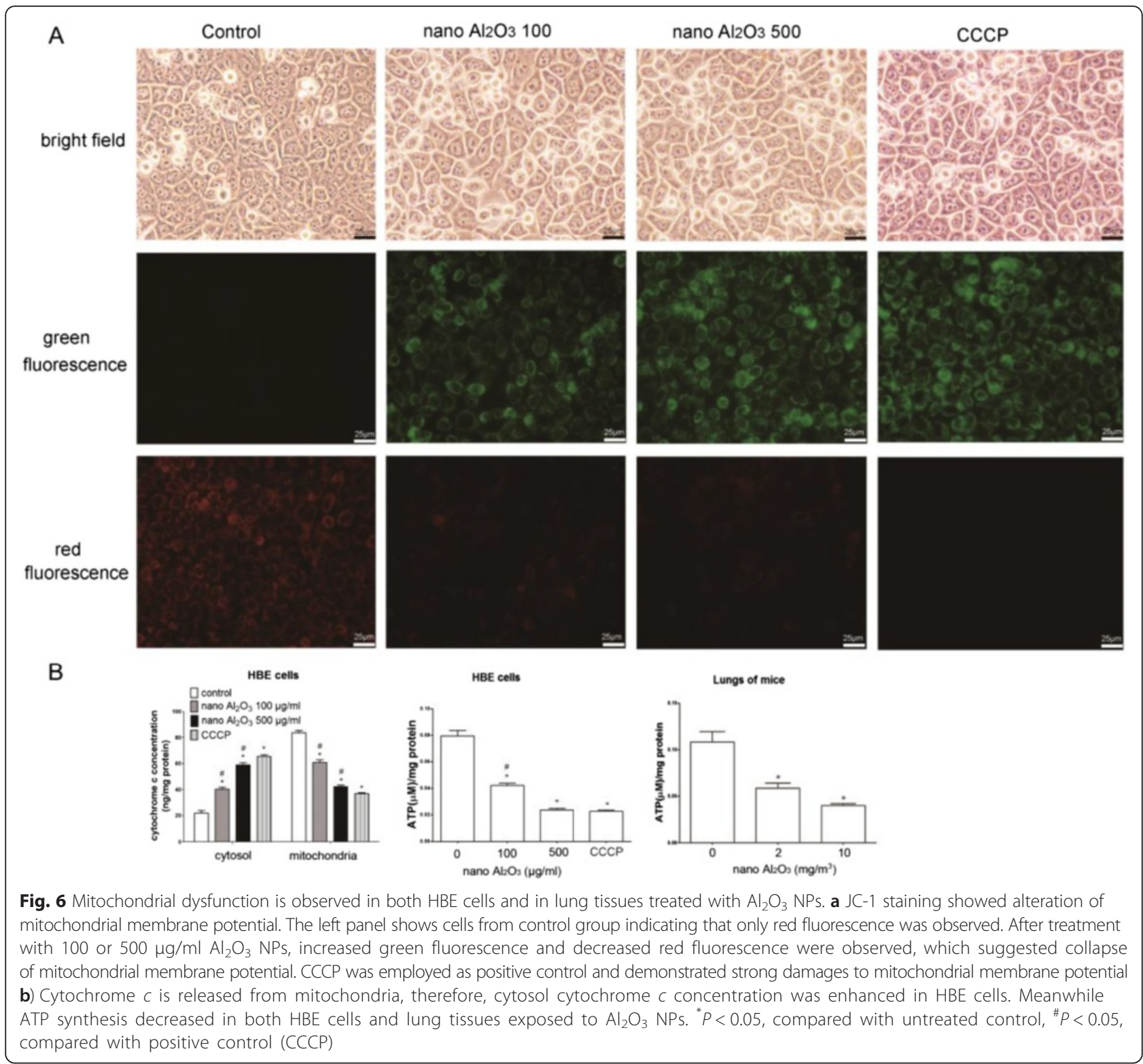

potential [34]. Nymark et al [33] combined transcriptome and microRNA analysis to identify mitochondrial dysfunctions induced by multi-walled carbon nanotubes and 26 genes with known mitochondrial function were identified. Additionally, GO analysis showed that the most significantly enriched biological process among the 26 differentially expressed genes was gluconeogenesis. Our studies suggest mRNA profiling analysis is a reasonable strategy to study the $\mathrm{Al}_{2} \mathrm{O}_{3} \mathrm{NP}$ toxicity on $\mathrm{HBE}$ cells. A total of 27 genes associated with the mitochondria correlated to $\mathrm{Al}_{2} \mathrm{O}_{3} \mathrm{NP}$ treatment. In contrast to Nymark's results, our array data suggested that oxidative phosphorylation was the most significantly affected biological process in treated cells. Gene expression levels were confirmed by qRT-PCR in HBE cells and mouse lung tissues exposed to $\mathrm{Al}_{2} \mathrm{O}_{3} \mathrm{NPs}$, further implicating altered mitochondrial function.

Mitochondria-mediated apoptosis is initiated by mitochondrial outer membrane permeabilization and release of cytochrome $c$ into the cytoplasm [6]. Cytochrome $c$ binds to apoptosis protease activating factor-1 (Apaf-1), which leads to activation of caspase- 9 and -3 , and is essential for DNA damage and apoptosis [35]. To determine whether differential expression of mitochondrial genes may lead to apoptosis, we monitored cell viability and mitochondrial function in cells and tissues exposed to $\mathrm{Al}_{2} \mathrm{O}_{3}$ NPs. Decreased mitochondrial membrane potential, increased caspase- 9 and -3 , and increased 


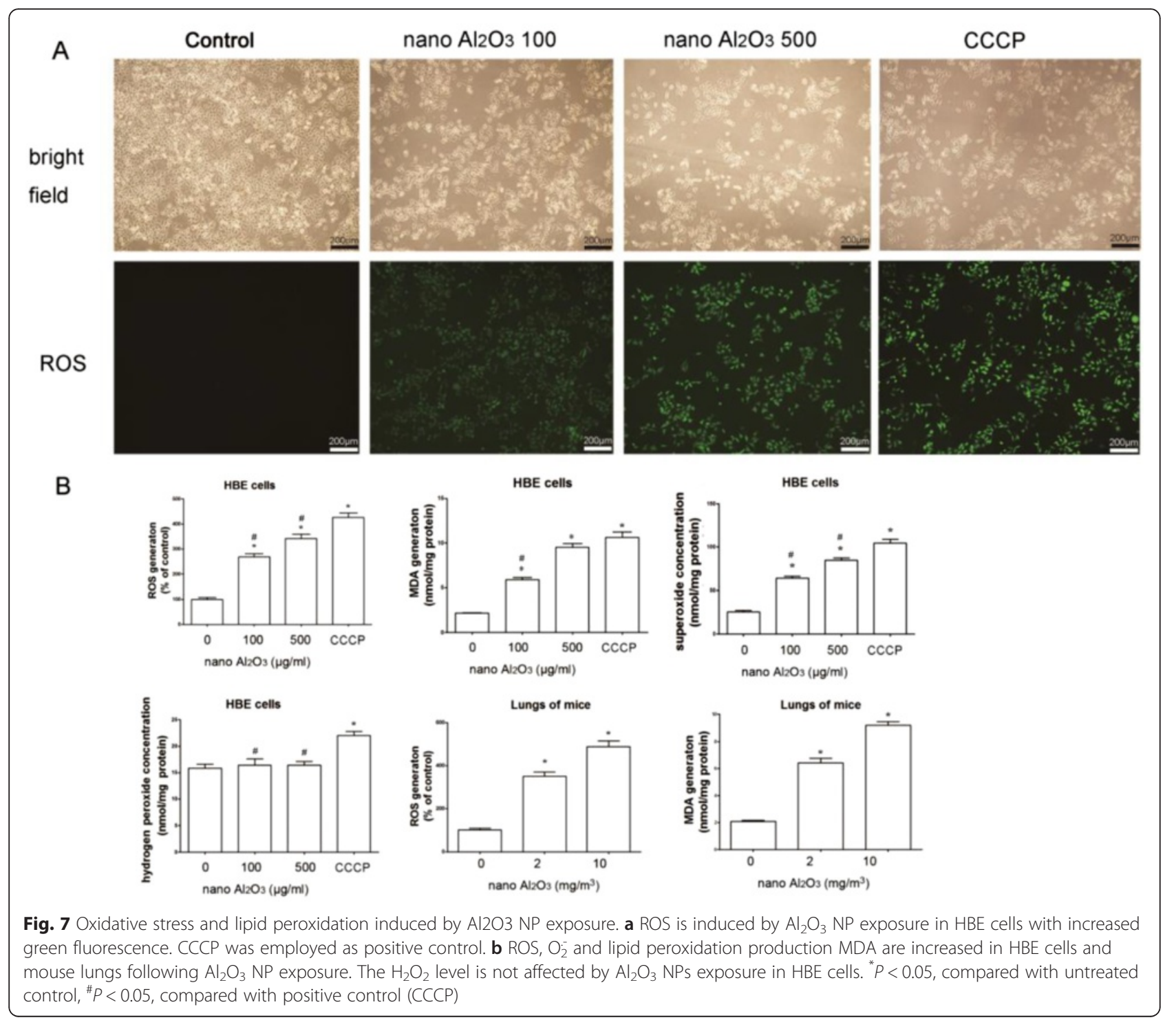

apoptosis were observed in cells and lung tissues exposed to $\mathrm{Al}_{2} \mathrm{O}_{3} \mathrm{NPs}$, suggesting $\mathrm{Al}_{2} \mathrm{O}_{3}$ NPs causes cytotoxic effects in the pulmonary tract.

Mitochondria are the primary source of cellular ROS, produced through oxidative phosphorylation, especially at levels of complexes I and III of the respiratory chain [36]. Excessive ROS production can lead to mitochondrial oxidative damage, which can lead to cell apoptosis. $\mathrm{O}_{2}^{-}$is an indicator of mitochondrial ROS production, and is generated by the addition of one electron to $\mathrm{O}_{2}$. Most intracellular ROS are derived from superoxide $\mathrm{O}_{2}^{-}$ and elicit various pathological events, including DNA damage and apoptosis [37-39]. Due to the small size and large surface area of nanoparticles, ROS are usually produced when cells are exposed to nanoparticles. As a result, oxidative stress and lipid peroxidation have been hypothesized to play an important role in nanoparticle toxicity $[34,40]$. In the present study, alteration of mitochondrial membrane potential, ROS and lipid peroxidation were significantly higher in HBE cells exposed to $\mathrm{Al}_{2} \mathrm{O}_{3} \mathrm{NPs}$ after 12 or $24 \mathrm{~h}$ treatment, while prominent enhancement of apoptosis and gene modulation were observed $24 \mathrm{~h}$ after treatment. Therefore, the mitochondriainvolved dysfunction could account for $\mathrm{Al}_{2} \mathrm{O}_{3}$ NPs induced gene modulations and subsequent apoptosis. Significantly, the antioxidant ALCAR reduced cell apoptosis effectively, suggesting that mitochondria associated oxidative stress is involved in $\mathrm{Al}_{2} \mathrm{O}_{3} \mathrm{NP}$ cytotoxicity.

The carnitine: acylcarnitine translocase (CACTL) located in the mitochondrial inner membrane facilitates cytosolic ALCAR entry into the mitochondria [41]. 
Table 2 Metabolomics analysis of $\mathrm{Al}_{2} \mathrm{O}_{3}$ NPs exposed HBE cell lysates

\begin{tabular}{|c|c|c|c|}
\hline Peak & Metabolic pathway & HMDB & Regulation \\
\hline 3-Phenylbutyric Acid & Taurine and Hypotaurine Metabolism & HMDB01955 & down \\
\hline Melatonin & Tryptophan Metabolism & HMDB01389 & down \\
\hline cis-Aconitic acid & Citric Acid Cycle & HMDB00072 & down \\
\hline 3-Methylhistidine & Histidine Metabolism & HMDB00479 & down \\
\hline Acetyl-L-carnitine & Beta Oxidation of Very Long Chain Fatty Acids & HMDB00201 & down \\
\hline 4-Methoxyphenylacetic acid & Tyrosine Metabolism & HMDB02072 & down \\
\hline N-Acetyl-L-methionine & Betaine Metabolism & HMDB11745 & down \\
\hline N-Formyl-L-methionine & Betaine Metabolism & HMDB01015 & down \\
\hline Pyridoxal 5'-phosphate & Vitamin B6 Metabolism & HMDB01491 & down \\
\hline L-Serine & Homocysteine Degradation & HMDB00187 & up \\
\hline Adenine & Phytanic Acid Peroxisomal Oxidation & HMDB00034 & up \\
\hline Succinic acid & Aspartate Metabolism & HMDB00254 & up \\
\hline D-Glutamic acid & Glutamate Metabolism & HMDB03339 & up \\
\hline Thymine & Pyrimidine Metabolism & HMDB00262 & up \\
\hline Ethylmalonic acid & Mefanamic Acid Pathway & HMDB00622 & up \\
\hline Ureidopropionic acid & Beta-Alanine Metabolism & HMDB00026 & up \\
\hline (-)Matairesinol & Phenylacetate Metabolism & HMDB35698 & up \\
\hline Taurocholic Acid & Bile Acid Biosynthesis & HMDB00036 & up \\
\hline Docosahexaenoic acid & Mefanamic Acid Pathway & HMDB02183 & up \\
\hline Pyridoxine & Vitamin B6 Metabolism & HMDB00239 & up \\
\hline
\end{tabular}

Inside the mitochondrial matrix, carnitine palmityltransferase II releases carnitine from ALCAR. Carnitine is then transported back across the membrane by carnitineacylcarnitine translocase [42]. Therefore, ALCAR is considered a specific intramitochondrial acetyl-donor and may be involved in restoring mitochondrial function [43]. ALCAR and its derivative L-carnitine supplementation have wide clinical applications to restore neurologic disorders [44] or improve liver function [42]. Our studies using metabolomics suggest ALCAR levels decrease dramatically due to $\mathrm{Al}_{2} \mathrm{O}_{3}$ NP exposure. Because ALCAR is reported to improve mitochondrial function and restore mitochondrial gene expression, [45] we supplemented HBE cells and mice with ALCAR during exposure to $\mathrm{Al}_{2} \mathrm{O}_{3}$ NPs. ALCAR treatment significantly increased cell viability and decreased apoptosis, corresponding to decreased caspase activity and cytochrome $c$ release. Additionally, ALCAR reduced oxidative stress and lipid peroxidation due to $\mathrm{Al}_{2} \mathrm{O}_{3} \mathrm{NP}$ exposure. ALCAR supplementation fully or partially rescued altered gene expression of mitochondrial-associated proteins due to $\mathrm{Al}_{2} \mathrm{O}_{3} \mathrm{NP}$ exposure. Consistent with our studies, treating rats with ALCAR rescued the function of complexes I, IV and V in brain mitochondria [46]. ALCAR additionally reduced ROS production and ATP depletion in an in vitro cell model [26]. We observed that ALCAR could partially restore oxidative stress and lipid peroxidation induced by a powerful mitochondrial uncoupling agent $\mathrm{CCCP}$, therefore demonstrating strong anti-oxidative activities in the present study.

NADH dehydrogenase (complex I) and cytochrome $c$ oxidase (complex IV) are highly susceptible to oxidative damage $[47,48]$. Our data indicate that genes involved in complex I, IV, and $\mathrm{V}$ were significantly downregulated in both $\mathrm{Al}_{2} \mathrm{O}_{3} \mathrm{NP}$-treated $\mathrm{HBE}$ cells and in lung tissues harvested from mice exposed to $\mathrm{Al}_{2} \mathrm{O}_{3}$ NPs, suggesting that loss of mitochondrial function may be due to compromised NADH-linked respiration and complex I-driven electron transport. Furthermore, our data suggests that ALCAR may be useful in maintaining ATP levels under specific pathologic conditions [21]. ALCAR can partially restore the gene expression level in complex I and completely restore gene expression level in complex IV and V, consistent with previous reports that ALCAR protects key mitochondrial enzymes (complex I and IV) from oxidative damage.

In the present study, ALCAR rescued $\mathrm{HBE}$ cells against $\mathrm{Al}_{2} \mathrm{O}_{3}$ NPs induced apoptosis, which is attributed to the anti-oxidative activities and gene restoration. Further, ALCAR could be a specific supplement according to our metabolomics assays because it was the most significantly down-regulated small molecule metabolite following $\mathrm{Al}_{2} \mathrm{O}_{3}$ NPs exposure. However, studies on the involved metabolic pathways and underlying mechanisms are further required. 

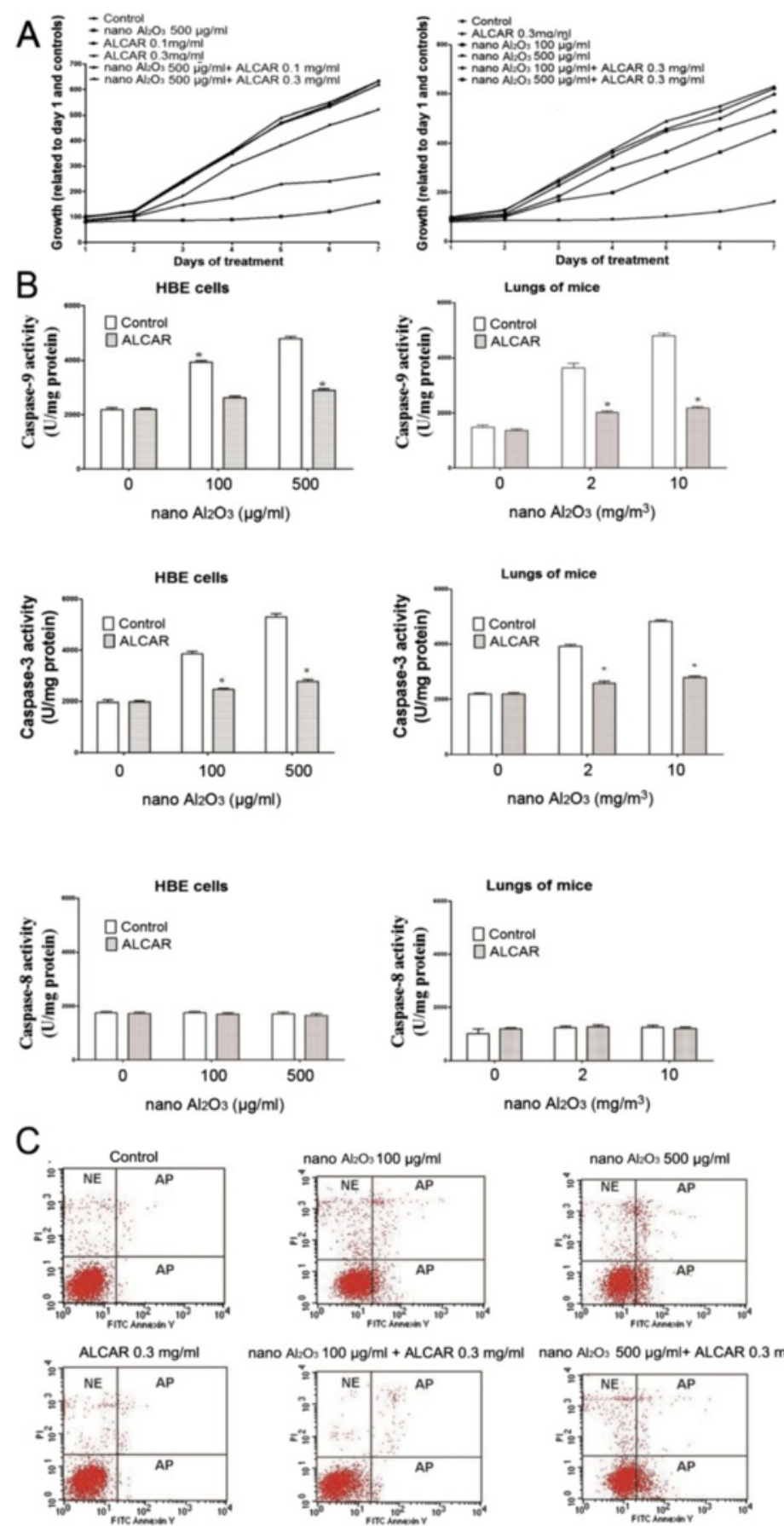

nano ALOS $100 \mu \mathrm{g} / \mathrm{ml}+$ ALCAR $0.3 \mathrm{mg} / \mathrm{ml}$ nano ALOS $500 \mu \mathrm{g} / \mathrm{ml}+$ ALCAR $0.3 \mathrm{mg} / \mathrm{ml}$
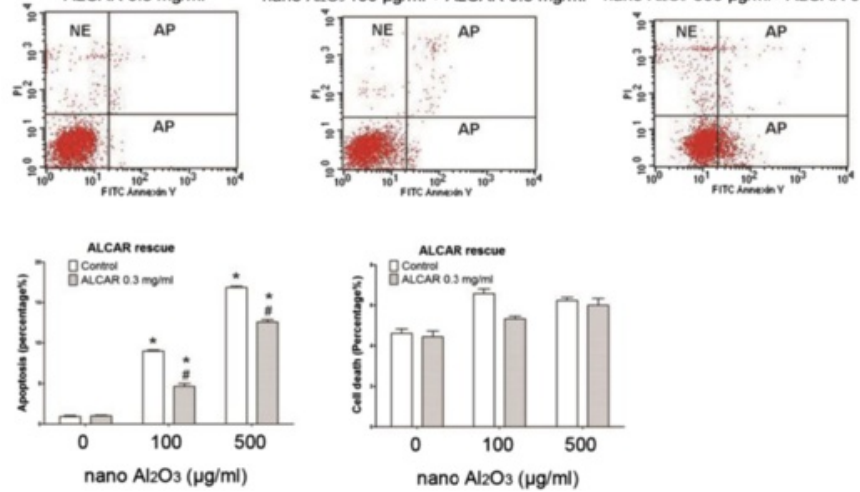

Fig. 8 (See legend on next page.)

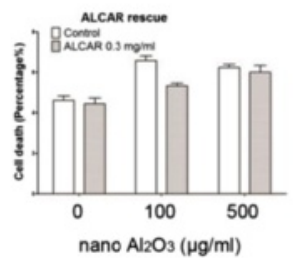


(See figure on previous page.)

Fig. 8 The ameliorative effects of ALCAR supplementation against cell viability lost and apoptosis. a $0.3 \mathrm{mg} / \mathrm{ml}$ ALCAR co-treatment effectively increased cell viability. $\mathbf{b} 0.3 \mathrm{mg} / \mathrm{ml}$ ALCAR co-treatment with $\mathrm{Al}_{2} \mathrm{O}_{3} \mathrm{NPs}$ ameliorated activities of caspase-3 and -9 completely or partially to control level in HBE cells by c) $0.3 \mathrm{mg} / \mathrm{ml}$ ALCAR co-treatment partially protected HBE cells from apoptosis induced by $\mathrm{Al}_{2} \mathrm{O}_{3} \mathrm{NPs}^{*}{ }^{*} P<0.05$, compared with untreated control, ${ }^{\#} P<0.05$, compared with corresponding control within each treatment group

\section{Conclusions}

In summary, we present a approach based on transcriptomics coupled with metabolomics methods, to reveal key genes involved in response to engineered $\mathrm{Al}_{2} \mathrm{O}_{3}$ NPs. These nano-scale $\mathrm{Al}_{2} \mathrm{O}_{3}$ particles are abundant in either occupational environments or as components of particulate matters in the ambient environment. RNA microarray revealed that down-regulated genes were mainly associated with mitochondrial complexes I and IV and oxidative stress. Treatment with the antioxidant ALCAR which is screened according to the metabolomics analysis was tested in our metabolomics study, and restored mitochondrial function through both in vivo and in vitro studies. We suggest that our "omics"

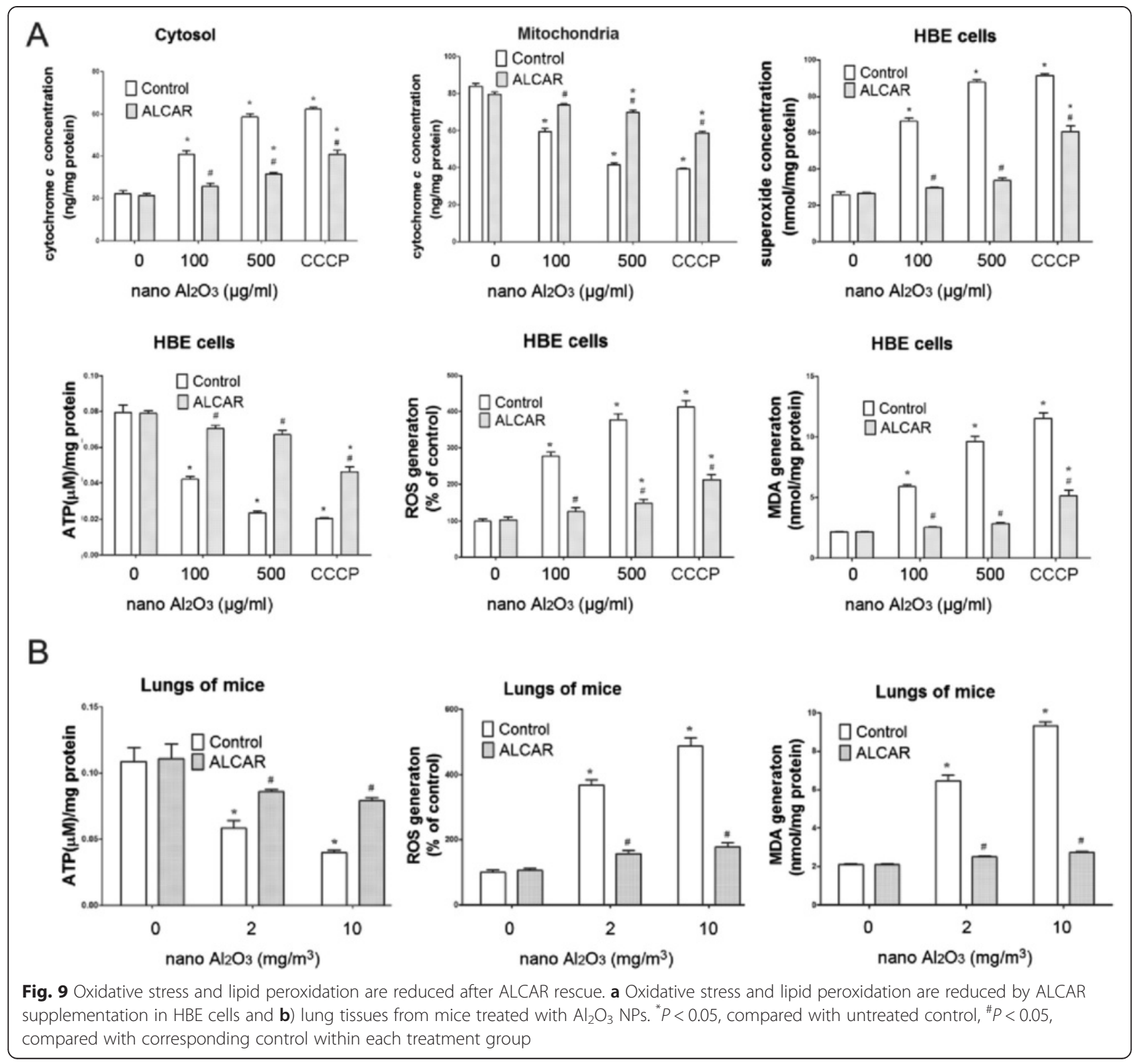




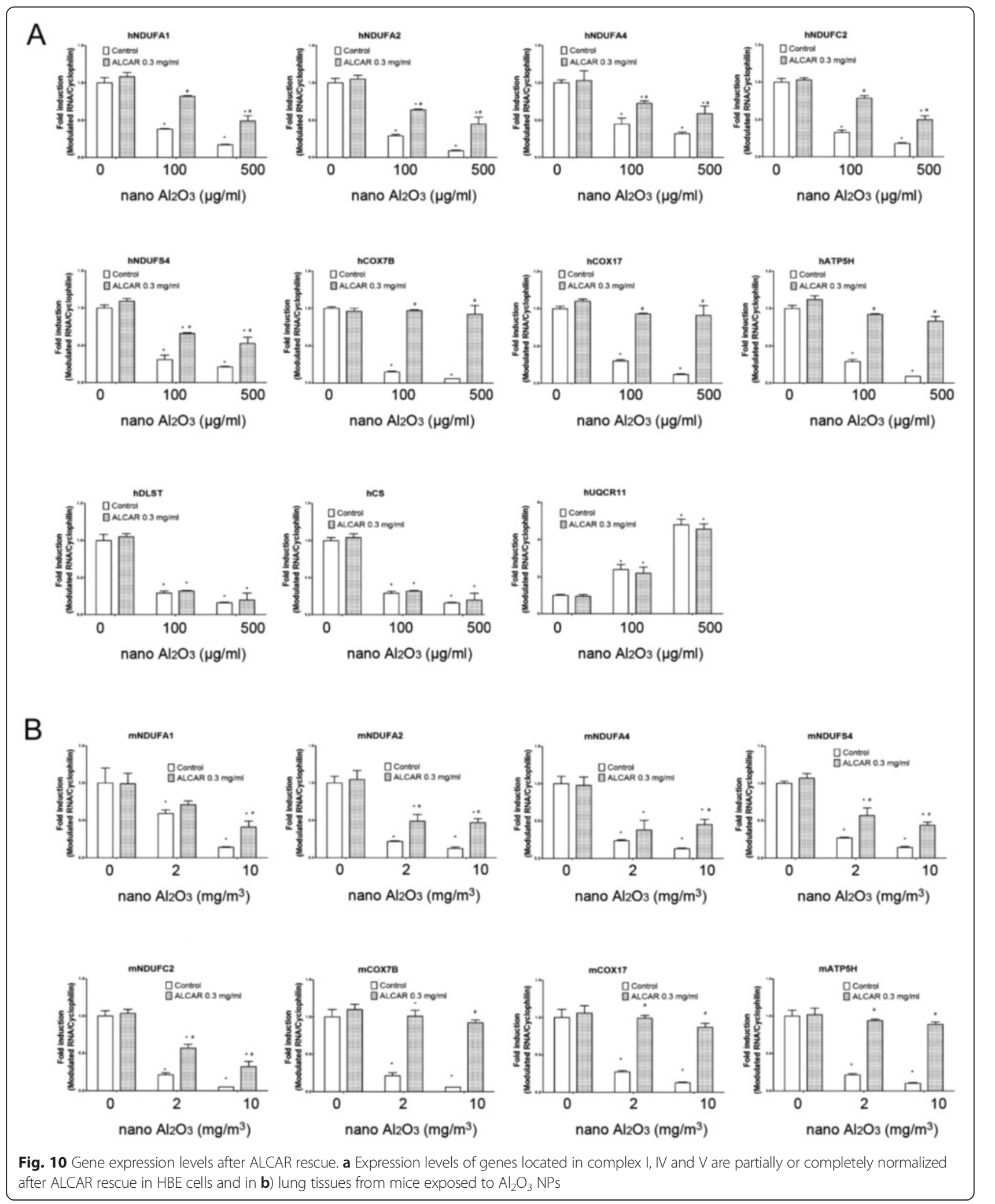

technologies can be used to identify specific pathways involved in toxicities due to $\mathrm{Al}_{2} \mathrm{O}_{3} \mathrm{NPs}$ and provides insight into identifying potential treatment solutions.
Our study is the first to demonstrate the use of ALCAR to restore mitochondrial function and protect cell toxicity from $\mathrm{Al}_{2} \mathrm{O}_{3} \mathrm{NP}$ exposure in vivo and in vitro. 


\section{Methods}

\section{Nanomaterials and animals}

$\mathrm{Al}_{2} \mathrm{O}_{3} \mathrm{NPs}$ were purchased from Plasmachem $\mathrm{GmbH}$, Germany ( $>99.8 \%$ purity). The particle size and zeta potential of $\mathrm{Al}_{2} \mathrm{O}_{3}$ NPs in PBS suspension was $64.17 \mathrm{~nm}$ and $37.1 \mathrm{mV}$, which was analyzed by a zetasizer (nanozs90, Malvern Instruments, UK) (Additional file 1: Figure S3).

Thirty-six male and 36 female ICR mice (20-22 g) were purchased from Shanghai SLRC Laboratory Animal Co. Ltd., China.

\section{Cell culture and RNA extraction}

The human bronchial epithelial cell line (HBE) (American Type Culture Collection) was maintained in Dulbecco's modified Eagle's medium (DMEM) at $37{ }^{\circ} \mathrm{C}$ in $5 \% \mathrm{CO}_{2}$. The culture medium was supplemented with $10 \%$ (v/v) fetal bovine serum (FBS), penicillin (100 U/ml), and streptomycin $(100 \mu \mathrm{g} / \mathrm{ml})$. Cells were seeded in $10 \mathrm{~cm}$ culture dishes and exposed to $100 \mu \mathrm{g} / \mathrm{ml} \mathrm{Al}_{2} \mathrm{O}_{3}$ NPs with three biological replicates. At $24 \mathrm{~h}$ post treatment, complete medium was removed and adherent cells were collected. Total RNA was extracted using the TRIZOL reagent (Invitrogen, U.S.) according to the manufacturer's instructions.

\section{RNA microarray and gene expression analysis}

An Agilent Array platform (Agilent Technologies, Santa Clara, CA, USA) was employed for microarray analysis. The labeled cRNAs were hybridized onto a Human LncRNA Array v3.0 $(8 \times 60 \mathrm{~K}$; arraystar $)$ chip designed for 26109 coding genes. The arrays were scanned using an Agilent G2505C scanner and the fluorescence intensity was analyzed with Agilent Feature Extraction software (version 11.0.1.1). Quantile normalization and subsequent data processing were performed using the GeneSpring Gx v12.0 software package (Agilent Technologies). An absolute fold change of 2 or more and 0.05 adjusted P-value were set as cutoff to evaluate the significance of gene expression differences of raw data.

\section{Functional group analysis}

DAVID 6.7 (Database for Annotation, Visualization, and Integrated Discovery), a functional annotation tool, was used to analyze differentially expressed genes. The DAVID functional annotation cluster tool provides three structured networks of defined terms that describe the attributes of gene products. The P-value was set to 0.1 to denote the significance of GO enrichment in the differentially expressed mRNA list. Fold enrichment (-lg ( $P$-value $))$ was used to denote the enrichment of a particular GO term. Pathway analysis for differentially expressed mRNAs was performed on the KEGG database. This analysis determines the biological pathways for which a significant enrichment of differentially expressed mRNAs exist ( $P$-value was set as 0.05$)$.

\section{Metabolomics analysis of $\mathrm{Al}_{2} \mathrm{O}_{3}$ NPs treated HBE cells} GC/TOFMS analysis was performed using an Agilent 7890 gas chromatography system coupled with a Pegasus 4D time-of-flight mass spectrometer. HBE cells were exposed to $\mathrm{Al}_{2} \mathrm{O}_{3}$ NPs $(0,100$, and $500 \mu \mathrm{g} / \mathrm{ml})$ for $24 \mathrm{~h}$ with 9 biological replicates. Then the cell lysate sample were prepared and analyzed as described [16].

\section{Animal treatment}

Mice were maintained and used according to the guidelines of the Committee on Animal Use and Care of Southeast University. The dynamic inhalation exposure chambers were outfitted with an aerosol generator (Beijing HuiRongHe Technology Co., Ltd, China). . Mice were divided into six groups (with six male and six female mice in each group): control, mice treated with $100 \mathrm{mg} / \mathrm{kg}$ ALCAR, mice treated with low and high doses of $\mathrm{Al}_{2} \mathrm{O}_{3}$ NPs, mice treated with a low dose of $\mathrm{Al}_{2} \mathrm{O}_{3} \mathrm{NPs}+100 \mathrm{mg} / \mathrm{kg}$ ALCAR, and mice treated with a high dose of $\mathrm{Al}_{2} \mathrm{O}_{3} \mathrm{NPs}+100 \mathrm{mg} / \mathrm{kg}$ ALCAR. Mice were housed six per polycarbonate cage on corncob bedding with ad libitum access to food and water. Exposure was carried out in three whole-body inhalation chambers; two chambers received low or high dose of $\mathrm{Al}_{2} \mathrm{O}_{3}$ NPs and the control chamber received HEPA-filtered clean air at the same flow rates as the experimental groups. Six males and six females were exposed in each chamber for $8 \mathrm{~h}$ per day for 7 consecutive days. Light cycles were set on a 12/12 h light/dark cycle. $\mathrm{Al}_{2} \mathrm{O}_{3} \mathrm{NPs}$ in the chamber were generated by the aerosol generator and mean concentrations of $\mathrm{Al}_{2} \mathrm{O}_{3}$ NPs were $2 \mathrm{mg} / \mathrm{m}^{3}$ and $10 \mathrm{mg} / \mathrm{m}^{3}$ for low and high dose treatments, respectively. The concentration of $\mathrm{Al}_{2} \mathrm{O} 3$ NPs were monitored by an extensive air quality monitoring equipment (CEL-712 Microdust Pro, CASELLA, UK). 100 mg/kg ALCAR was orally administrated by gavage. The temperature, air flow rate and relative humidity in the chambers was set to $22.5{ }^{\circ} \mathrm{C}, 40 \mathrm{~L} / \mathrm{min}$, and $50 \pm 10 \%$.

\section{Histopathological analysis of mice lung tissue}

Mice were euthanized under ether anesthesia $1 \mathrm{~h}$ after the end of dynamic $\mathrm{Al}_{2} \mathrm{O}_{3} \mathrm{NP}$ exposure on the $7^{\text {th }}$ day. All the mice were decaptitated on an iced table. Lung tissue was divied for three parts. One piece was immediately prepared for capasse activity, ATP level, ROS and MDA analysis. The second piece was stored in liquid nitrogen, while another piece was preserved in $4 \%$ paraformaldehyde (PFA) for $24 \mathrm{~h}$ at $4{ }^{\circ} \mathrm{C}$, embedded in paraffin, serially sectioned $(5 \mu \mathrm{m})$ and mounted on silanecovered slides. After dewaxing, the sections selected from 
each mouse were stained with hematoxylin and eosin (HE) and evaluated under a light microscope $(400 \times)$ to examine the histology of the lung tissues. The severity of pathological lesions was scored according to Szapiel's method (Additional file 1: Table S1) [49].

Apoptotic cells in lung tissues were evaluated through Terminal-deoxynucleoitidyl transferase mediated nick end labeling (TUNEL) staining by a Roche In Situ Cell Death Detection Kit (Roche, U.S.) according to the suggested protocols. The proportion of TUNEL-positive cells of bronchial epithelia were estimated by an experienced histologists blinded to treatment conditions. Five non-overlapping bronchial tubes of each section were counted in high-power fields (HPFS, $\times 400$ magnification) and analyzed. The bronchial tubes had a maximum of positive cells were selected.

\section{Cell viability}

Cellular viability was evaluated by a CCK- 8 proliferation assay using a Cell Counting Kit-8 (Nanjing Jiancheng Bioengineering Institute, China). HBE cells were plated at a density of $1 \times 10^{4}$ per well in a 96-well plate and treated with $0,12.5,25,50,100,250,500,1000 \mu \mathrm{g} / \mathrm{ml}$ (corresponding to $0,3.91,7.81,15.62,31.25,78.13$, 156.25, $\left.312.5 \mu \mathrm{g} / \mathrm{cm}^{2}\right) \mathrm{Al}_{2} \mathrm{O}_{3}$ NPs with eight biological replicates for each concentration. $10 \mu \mathrm{L}$ of CCK- 8 was added to each well, cells were incubated for $4 \mathrm{~h}$ at $37^{\circ} \mathrm{C}$, and the absorbance was determined at $450 \mathrm{~nm}$. Cell viability affected by $\mathrm{Al}_{2} \mathrm{O}_{3}$ NPs were monitored every $24 \mathrm{~h}$ for up to 7 days.

\section{Cell apoptosis analysis}

Apoptosis was assessed by flow cytometry using a KeyGEN Annexin V-FITC Apoptosis Detection Kit (KeyGEN BioTECH, China) according to the manufacturer's instructions. Briefly, after exposure to 100 or $500 \mu \mathrm{g} / \mathrm{ml}$ $\mathrm{Al}_{2} \mathrm{O}_{3}$ NPs for 12 or $24 \mathrm{~h}, \mathrm{HBE}$ cells were harvested and incubated with $5 \mu \mathrm{l}$ FITC-conjugated annexin V and $5 \mu \mathrm{l}$ PI for $15 \mathrm{~min}$ at room temperature in the dark. The samples were analyzed by a FACS Calibur Flow Cytometer (BD Biosciences, USA).

\section{Assessment of caspase-3, caspase-8, and caspase-9 activities}

Caspase activity assay kits (Beyotime Institute of Biotechnology, China) were used to evaluate caspase-3, 8, and 9 activities in HBE cell lysates and lung tissues according to the manufacturer's instructions. Briefly, $0.05 \mathrm{~g}$ lung tissues were homogenized with $500 \mu \mathrm{l}$ lysis buffer on ice. cells were lysed with lysis buffer. Protein content was measured by the Bradford method. Ac-DEVDpNA, Ac-IETD- $p$ NA, Ac-LEHD- $p$ NA were substrate peptides of caspase-3, 8, and 9 respectively, and incubated with $\mathrm{Al}_{2} \mathrm{O}_{3} \mathrm{NPs}$-treated cell or lung tissue lysate for $2 \mathrm{~h}$ at $37^{\circ} \mathrm{C}$.
The release of p-nitroanilide (pNA) from substrates was measured at $405 \mathrm{~nm}$ by a microplate reader (Molecular Devices, U.S.).

\section{Mitochondria functions analysis}

ATP levels were measured using a luciferase ATP assay kit (Beyotime, China). Briefly, $200 \mu \mathrm{L}$ of lysis buffer was added to cells treated or untreated with $\mathrm{Al}_{2} \mathrm{O}_{3}$ NPs. Cells were collected and centrifuged at $12000 \mathrm{rpm}$ for $5 \mathrm{~min}$ at $4{ }^{\circ} \mathrm{C}$. $0.05 \mathrm{~g}$ lung tissue were homogenized with $250 \mu \mathrm{l}$ lysis buffer, then centrifuged at $12,000 \mathrm{rpm}$ for $5 \mathrm{~min}$ at $4{ }^{\circ} \mathrm{C}$. The luminescence of the supernatant was assayed by a luminometer (Berthold Detection System, Pforzheim, Germany). The cationic dye JC-1 was used to detect the mitochondrial membrane potential, and HBE cells exposed to $\mathrm{Al}_{2} \mathrm{O}_{3}$ NPs 12 or $24 \mathrm{~h}$ were evaluated under a fluorescence microscope (Olympus, Japan) to examine green and red fluorescence.

To determine the release of cytochrome $c$, mitochondrial and cytosolic proteins were isolated by a Mitochondria/Cytosol Fractionation Kit (Beyotime, China) according to the manufacturer's instructions. The protein concentrations in cytosol and mitochondria samples were measured using the Bradford method. The levels of cytochrome $c$ were estimated according to the ELISA kit procedures (R\&D Systems, U.S.). For all of these mitochondrial-involved assays, CCCP was employed as positive control.

\section{Measurements of reactive oxygen species (ROS), superoxide $\left(\mathrm{O}_{2}^{-}\right)$, hydrogen peroxide $\left(\mathrm{H}_{2} \mathrm{O}_{2}\right)$ and malondialdehyde (MDA) levels}

After 12 or $24 \mathrm{~h}$ exposure to 100 or $500 \mu \mathrm{g} / \mathrm{ml} \mathrm{Al} 2 \mathrm{O} 3$ NPs, HBE cells were washed with PBS. $0.05 \mathrm{~g}$ fresh mice lung were homogenized by with $1 \mathrm{~mL}$ PBS, and centrifuged at $1,600 \mathrm{~g}$ for $10 \mathrm{~min}$ at $4{ }^{\circ} \mathrm{C}$. Then DCFH-DA probe was added (Beyotime, China) with a final concentration of $10 \mu \mathrm{mol} / \mathrm{L}$ to determine the content of intracellular ROS. The fluorescence intensity was measured after $30 \mathrm{~min}$ incubation at $37{ }^{\circ} \mathrm{C}$ under a fluorescence microscope (Olympus, Japan), and quantified by a fluorescence spectrophotometer. $\mathrm{O}_{2}^{-}$levels in the cell lysate were determined by WST-1 assay. The concentration of formazan, the reduced product of NBT was measured at $560 \mathrm{~nm} . \mathrm{H}_{2} \mathrm{O}_{2}$ concentration in cells was determined by optical density (OD) at $560 \mathrm{~nm}$, indicative of $\mathrm{H}_{2} \mathrm{O}_{2}$ oxidization of trivalent ferric and xylenol orange. The concentrations of MDA in cellular and lung tissue lysate were assessed by measuring thiobarbituric-acid (TBA) reacting substances at $532 \mathrm{~nm}$. The level of MDA was expressed as nmol MDA per milligram protein. Protein content was measured by Bradford method. For all of these oxidative stress and lipid peroxidation related assays, CCCP was employed as positive control. 


\section{ALCAR rescue to $\mathrm{Al}_{2} \mathrm{O}_{3} \mathrm{NPs}$ induced mitochondrial dysfunction}

Cell viability of $\mathrm{HBE}$ cells treated with PBS, 0.1, $0.3 \mathrm{mg} / \mathrm{ml}$ ALCAR, $500 \mu \mathrm{g} / \mathrm{ml} \mathrm{Al}_{2} \mathrm{O}_{3} \mathrm{NPs}, 0.1 \mathrm{mg} / \mathrm{ml}$ $\mathrm{ALCAR}+500 \mu \mathrm{g} / \mathrm{ml} \mathrm{Al}_{2} \mathrm{O}_{3} \mathrm{NPs}$, or $0.3 \mathrm{mg} / \mathrm{ml} \mathrm{ALCAR} \mathrm{+}$ $500 \mu \mathrm{g} / \mathrm{ml} \mathrm{Al} \mathrm{O}_{2} \mathrm{O}$ NPs was assessed to determine an appropriate therapeutic dose of ALCAR.

To validate the protective effects of ALCAR against mitochondrial dysfunction, $\mathrm{HBE}$ cells were treated with PBS, 100, $500 \mu \mathrm{g} / \mathrm{ml} \mathrm{Al}_{2} \mathrm{O}_{3} \mathrm{NPs}, 0.3 \mathrm{mg} / \mathrm{ml} \mathrm{ALCAR}$, $0.3 \mathrm{mg} / \mathrm{ml} \mathrm{ALCAR+} 100 \mu \mathrm{g} / \mathrm{ml} \mathrm{Al}_{2} \mathrm{O}_{3} \mathrm{NPs}$ or $0.3 \mathrm{mg} / \mathrm{ml}$ ALCAR+ $500 \mu \mathrm{g} / \mathrm{ml} \mathrm{Al}_{2} \mathrm{O}_{3} \mathrm{NPs}$ for $24 \mathrm{~h}$. Then mitochondrial membrane potential, ROS, ATP, MDA levels, caspase-3, 8, and 9 activities, and $\mathrm{O}_{2}^{-}$levels in $\mathrm{HBE}$ cells were determined.

\section{RNA isolation and quantitative real-time PCR assay}

HBE cells were seeded in 6-well plates at a density of about $1 \times 10^{6}$ cells per well, and exposed to 50, 100, 250, or $500 \mu \mathrm{g} / \mathrm{ml} \mathrm{Al}_{2} \mathrm{O}_{3} \mathrm{NPs}$ or control medium for $24 \mathrm{~h}$, then cells were trypsinized and collected. The mice lung tissue stored in liquid nitrogen were homogenized in ice-cold $50 \mathrm{mM}$ Tris- $\mathrm{HCl}$ buffer ( $\mathrm{pH} 7.55$ ).

Total RNA of HBE cells and lung tissues were extracted using a GenElute ${ }^{\mathrm{TM}}$ Mammalian Total RNA Miniprep Kit (Sigma, U.S.) according to the manufacturer's protocol, and the concentration of total RNA was determined by measuring the absorbance at $260 \mathrm{~nm}$ using a Nanodrop 2000c spectrophotometer (Thermo Scientific, U.S.). cDNA synthesis for coding genes was performed with lug of total RNA according to the manufacturer's instruction (Takara, Japan).

The mRNA levels for modulated genes were determined by reverse transcription of total RNA followed by quantitative real-time PCR analysis (qRT-PCR) on a Quant Studio 6 Flex system (Applied Biosystems, Life Technologies, U.S.) using SYBR PCR Master Mix reagent kits (Takara, Japan) following the manufacturer's protocol. Primers were designed for the modulated genes screened by RNA microarray, and are provided in Additional file 1: Table S2 and S3. All experiments were performed in triplicate. The mRNA levels provided were normalized to cyclophilin A.

\section{Data analysis}

Values of cell viability, apoptosis, and mitochondrial dysfunction assays are expressed as mean \pm standard error of the mean (SE). Statistically significant differences were determined by one-way ANOVA, followed by Dunnett's multiple comparison tests. Kruskal-Wallis test was used to analyze the ranked data of pulmonary lesion scores. The method of $2^{-\Delta \Delta C t}$ was used to analyze the results of RT-PCR in all experiments. Statistical analysis was performed by SPSS12.0 and the significance was set at $P<0.05$.

\section{Additional file}

Additional file 1: Supplementary documents Figure S1-3 with figure legend and Tables S1-3. (PDF $793 \mathrm{~kb}$ )

\begin{abstract}
Abbreviations
$\mathrm{Al}_{2} \mathrm{O}_{3}$ : aluminum oxide; ALCAR: acetyl-L-carnitine; Apaf-1: apoptosis protease activating factor-1; CACTL: carnitine: acylcarnitine translocase; FBS: fetal bovine serum; GO: gene ontology; GSH: glutathione; $\mathrm{H}_{2} \mathrm{O}_{2}$ : hydrogen peroxide; HBE: human bronchial epithelial; HE: hematoxylin and eosin; HEPG2: human hepatocarcinoma; KEGG: Kyoto encyclopedia of genes and genomes; MDA: malondialdehyde; MOMP: mitochondrial outer membrane permeabilization; NPs: nanoparticles; $\mathrm{O}_{2}$ : superoxide; PFA: paraformaldehyde; $\mathrm{PM}_{2.5}$ : fine particulate matter; ROS: reactive oxygen species; SE: standard error of the mean; SWCNTs: single-walled carbon nanotubes; TBA: thiobarbituric-acid.
\end{abstract}

\section{Competing interests}

The authors declare no competing financial interest.

\section{Authors' contributions}

$\mathrm{RC}, \mathrm{YX}$ conceived, designed and directed the study. $\mathrm{XL}, \mathrm{CZ}, \mathrm{XZ}, \mathrm{SW}$ performed and directed experiments. QM, SW contributed animal experiments. HY contributed to the pathologyanalysis. NG performed bioinformation analyses. All authors approved the final manuscript and contributed critical revisions to its intellectual content.

\section{Acknowledgements}

This work was financially supported by National Natural Science Foundation of China (Grant No. 81472938), the Natural Science Foundation of Jiangsu Province (BK20151418), the fund of the Distinguished talents of Jiangsu Province (BK20150021) the fund of the Distinguished Professor of Jiangsu Province, the Open Research Fund of State Key Laboratory of Bioelectronics, Southeast University, the fund of the post-graduate innovative talents (Grant No. SJZZ_0033), and the Fundamental Research Funds for the Central Universities. We thank Nanjing Milestone Biotechnology Co. LTD for mRNA microarray and metabolomics data processing for this manuscript.

\section{Author details}

${ }^{1}$ Key Laboratory of Environmental Medicine Engineering, Ministry of Education, School of Public Health, Southeast University, Dingjiaqiao 87, Nanjing 210009, China. ${ }^{2}$ Center for Drug Safety Evaluation and Research, China Pharmaceutical University, Nanjing 211198, China. ${ }^{3}$ Key Laboratory of Modern Toxicology of Ministry of Education, School of Public Health, Nanjing Medical University, Nanjing 211166, China. ${ }^{4}$ State Key Laboratory of Bioelectronics, Southeast University, Nanjing 210096, China.

Received: 14 July 2015 Accepted: 11 January 2016

Published online: 16 January 2016

\section{References}

1. Mills NL, Donaldson K, Hadoke PW, Boon NA, MacNee W, Cassee FR, et al. Adverse cardiovascular effects of air pollution. Nat Clin Pract Cardiovasc Med. 2009;6:36-44.

2. Lu S, Zhang W, Zhang R, Liu P, Wang Q, Shang Y, et al. Comparison of cellular toxicity caused by ambient ultrafine particles and engineered metal oxide nanoparticles. Part Fibre Toxicol. 2015;12:5.

3. Huang Y, Lu X, Ma J. Toxicity of silver nanoparticles to human dermal fibroblasts on microRNA level. J Biomed Nanotechnol. 2014;10:3304-17.

4. Thit A, Selck H, Bjerregaard HF. Toxic mechanisms of copper oxide nanoparticles in epithelial kidney cells. Toxicol In Vitro. 2015;29:1053-9.

5. Shi Y. A structural view of mitochondria-mediated apoptosis. Nat Struct Biol. 2001;8:394-401.

6. Xiong S, Mu T, Wang G, Jiang X. Mitochondria-mediated apoptosis in mammals. Protein Cell. 2014;5:737-49.

7. Nakahira K, Haspel JA, Rathinam VA, Lee SJ, Dolinay T, Lam HC, et al. Autophagy proteins regulate innate immune responses by inhibiting the release of mitochondrial DNA mediated by the NALP3 inflammasome. Nat Immunol. 2011;12:222-30. 
8. Talla V, Koilkonda R, Porciatti V, Chiodo V, Boye SL, Hauswirth WW, et al. Complex I subunit gene therapy with NDUFA6 ameliorates neurodegeneration in EAE. Invest Ophthalmol Vis Sci. 2015;56:1129-40.

9. Cao X, Yap JL, Newell-Rogers MK, Peddaboina C, Jiang W, Papaconstantinou $\mathrm{HT}$, et al. The novel BH3 alpha-helix mimetic JY-1-106 induces apoptosis in a subset of cancer cells (lung cancer, colon cancer and mesothelioma) by disrupting $\mathrm{BCl}-\mathrm{xL}$ and $\mathrm{Mcl}-1$ protein-protein interactions with Bak. Mol Cancer. 2013;12:42

10. Fulda S, Galluzzi L, Kroemer G. Targeting mitochondria for cancer therapy. Nat Rev Drug Discov. 2010;9:447-64

11. Li R, Kou X, Geng H, Xie J, Tian J, Cai Z, et al. Mitochondrial damage: an important mechanism of ambient PM2.5 exposure-induced acute heart injury in rats. J Hazard Mater. 2015;287:392-401.

12. Stapleton PANC, Yi J, McBride CR, Minarchick VC, Shepherd DL, Hollander $\mathrm{JM}$, et al. Microvascular and mitochondrial dysfunction in the female F1 generation after gestational TiO2 nanoparticle exposure. Nanotoxicology. 2014:5:1-11

13. Yu KN, Yoon TJ, Minai-Tehrani A, Kim JE, Park SJ, Jeong MS, et al. Zinc oxide nanoparticle induced autophagic cell death and mitochondrial damage via reactive oxygen species generation. Toxicol In Vitro. 2013;27:1187-95.

14. Collins FS, Gray GM, Bucher JR. Toxicology. Transforming environmental health protection. Science. 2008;319:906-7.

15. Nel A, Xia T, Meng H, Wang X, Lin S, Ji Z, et al. Nanomaterial toxicity testing in the 21st century: use of a predictive toxicological approach and high-throughput screening. Acc Chem Res. 2013;46:607-21.

16. Xu B, Chen M, Ji X, Mao Z, Zhang X, Wang X, et al. Metabolomic profiles delineate the potential role of glycine in gold nanorod-induced disruption of mitochondria and blood-testis barrier factors in TM-4 cells. Nanoscale. 2014;6:8265-73.

17. Hanagata N, Zhuang F, Connolly S, Li J, Ogawa N, Xu M. Molecular responses of human lung epithelial cells to the toxicity of copper oxide nanoparticles inferred from whole genome expression analysis. ACS Nano. 2011;5:9326-38.

18. Foldbjerg R, Irving ES, Hayashi Y, Sutherland DS, Thorsen $K$, Autrup $H$, et al. Global gene expression profiling of human lung epithelial cells after exposure to nanosilver. Toxicol Sci. 2012;130:145-57.

19. Shim W, Paik MJ, Nguyen DT, Lee JK, Lee Y, Kim JH, et al. Analysis of changes in gene expression and metabolic profiles induced by silica-coated magnetic nanoparticles. ACS Nano. 2012;6:7665-80.

20. Pettegrew JW, Levine J, McClure RJ. Acetyl-L-carnitine physical-chemical, metabolic, and therapeutic properties: relevance for its mode of action in Alzheimer's disease and geriatric depression. Mol Psychiatry. 2000;5:616-32.

21. Patel SP, Sullivan PG, Lyttle TS, Rabchevsky AG. Acetyl-L-carnitine ameliorates mitochondrial dysfunction following contusion spinal cord injury. J Neurochem. 2010;114:291-301.

22. Musicco C, Capelli V, Pesce V, Timperio AM, Calvani M, Mosconi L, et al. Accumulation of overoxidized Peroxiredoxin III in aged rat liver mitochondria. Biochim Biophys Acta. 2009;1787:890-6.

23. Aureli T, Puccetti C, Di Cocco ME, Arduini A, Ricciolini R, Scalibastri M, et al, Entry of [(1,2-13C2)acetyl]-L-carnitine in liver tricarboxylic acid cycle and lipogenesis: a study by 13C NMR spectroscopy in conscious, freely moving rats. Eur J Biochem. 1999;263:287-93.

24. Annadurai T, Vigneshwari S, Thirukumaran R, Thomas PA, Geraldine P. Acetyl-L-carnitine prevents carbon tetrachloride-induced oxidative stress in various tissues of Wistar rats. J Physiol Biochem. 2011;67:519-30.

25. Di Cesare ML, Ghelardini C, Calvani M, Nicolai R, Mosconi L, Vivoli E, et al. Protective effect of acetyl-L-carnitine on the apoptotic pathway of peripheral neuropathy. Eur J Neurosci. 2007;26:820-7.

26. Dhitavat S, Ortiz D, Shea TB, Rivera ER. Acetyl-L-carnitine protects against amyloid-beta neurotoxicity: roles of oxidative buffering and ATP levels. Neurochem Res. 2002;27:501-5.

27. Lambrecht BN, Hammad H. The airway epithelium in asthma. Nat Med. 2012;18:684-92.

28. Madl AK, Plummer LE, Carosino C, Pinkerton KE. Nanoparticles, lung injury, and the role of oxidant stress. Annu Rev Physiol. 2014;76:447-65.

29. Shvedova AA, Kisin E, Murray AR, Johnson VJ, Gorelik O, Arepalli S, et al. Inhalation vs. aspiration of single-walled carbon nanotubes in C57BL/6 mice: inflammation, fibrosis, oxidative stress, and mutagenesis. Am J Physiol Lung Cell Mol Physiol. 2008;295:L552-65.
30. Sager T, Wolfarth M, Keane M, Porter D, Castranova V, Holian A. Effects of nickel-oxide nanoparticle pre-exposure dispersion status on bioactivity in the mouse lung. Nanotoxicology. 2015;28:1-11.

31. Pisani C, Gaillard JC, Nouvel V, Odorico M, Armengaud J, Prat O. High-throughput, quantitative assessment of the effects of low-dose silica nanoparticles on lung cells: grasping complex toxicity with a great depth of field. BMC Genomics. 2015;16:315.

32. Pinkerton KE, Green FH, Saiki C, Vallyathan V, Plopper CG, Gopal V, et al. Distribution of particulate matter and tissue remodeling in the human lung. Environ Health Perspect. 2000;108:1063-9.

33. Nymark $P$, Wijshoff $P$, Cavill R, van Herwijnen M, Coonen ML, Claessen S, et al. Extensive temporal transcriptome and microRNA analyses identify molecular mechanisms underlying mitochondrial dysfunction induced by multi-walled carbon nanotubes in human lung cells. Nanotoxicology. 2015:9(5):624-35.

34. Siddiqui MA, Alhadlaq HA, Ahmad J, Al-Khedhairy AA, Musarrat J, Ahamed M. Copper oxide nanoparticles induced mitochondria mediated apoptosis in human hepatocarcinoma cells. PLoS One. 2013;8:e69534.

35. Youle RJ, Strasser A. The BCL-2 protein family: opposing activities that mediate cell death. Nat Rev Mol Cell Biol. 2008:9:47-59.

36. Marchi S, Giorgi C, Suski JM, Agnoletto C, Bononi A, Bonora M, et al. Mitochondria-ros crosstalk in the control of cell death and aging. J Signal Transduct. 2012;2012:329635.

37. Van Houten B, Woshner V Santos JH. Role of mitochondrial DNA in toxic responses to oxidative stress. DNA Repair (Amst). 2006;5:145-52.

38. AshaRani PV, Low Kah Mun G, Hande MP, Valiyaveettil S. Cytotoxicity and genotoxicity of silver nanoparticles in human cells. ACS Nano. 2009;3:279-90.

39. Ahamed M, Akhtar MJ, Raja M, Ahmad I, Siddiqui MK, AlSalhi MS, et al. ZnO nanorod-induced apoptosis in human alveolar adenocarcinoma cells via p53, survivin and bax/bcl-2 pathways: role of oxidative stress. Nanomedicine. 2011;7:904-13.

40. Manke A, Wang L, Rojanasakul Y. Mechanisms of nanoparticle-induced oxidative stress and toxicity. Biomed Res Int. 2013;2013:942916.

41. Indiveri C, lacobazzi V, Tonazzi A, Giangregorio N, Infantino V, Convertini $P$, et al. The mitochondrial carnitine/acylcarnitine carrier: function, structure and physiopathology. Mol Aspects Med. 2011;32:223-33.

42. Kathirvel E, Morgan K, French SW, Morgan TR. Acetyl-L-carnitine and lipoic acid improve mitochondrial abnormalities and serum levels of liver enzymes in a mouse model of nonalcoholic fatty liver disease. Nutr Res. 2013;33:932-41.

43. Tong X, Christian P, Zhao M, Wang H, Moreau R, Su Q. Activation of hepatic $\mathrm{CREBH}$ and Insig signaling in the anti-hypertriglyceridemic mechanism of R-alpha-lipoic acid. J Nutr Biochem. 2015;26(9):921-8.

44. Malaguarnera M. Carnitine derivatives: clinical usefulness. Curr Opin Gastroenterol. 2012;28:166-76.

45. Cassano P, Sciancalepore AG, Pesce V, Fluck M, Hoppeler H, Calvani M, et al. Acetyl-L-carnitine feeding to unloaded rats triggers in soleus muscle the coordinated expression of genes involved in mitochondrial biogenesis. Biochim Biophys Acta. 2006;1757:1421-8.

46. Long J, Gao F, Tong L, Cotman CW, Ames BN, Liu J. Mitochondrial decay in the brains of old rats: ameliorating effect of alpha-lipoic acid and acetyl-L-carnitine. Neurochem Res. 2009;34:755-63.

47. Vazquez-Memije ME, Capin R, Tolosa A, El-Hafidi M. Analysis of age-associated changes in mitochondrial free radical generation by rat testis. Mol Cell Biochem. 2008;307:23-30.

48. Roy Chowdhury SK, Sangle GV, Xie X, Stelmack GL, Halayko AJ, Shen GX. Effects of extensively oxidized low-density lipoprotein on mitochondrial function and reactive oxygen species in porcine aortic endothelial cells. Am J Physiol Endocrinol Metab. 2010;298:E89-98.

49. Szapiel SVEN, Fulmer JD, Hunninghake GW, Crystal RG. Bleomycin-induced interstitial pulmonary diseases in the nude, athymic mouse. Am Rev Resp Dis. 1979:120:7. 